\title{
Sediment Estimation and Assessment of Hydraulic Structure of Hirna Small Scale Irrigation Scheme, West Hararghe Zone Oromia Regional State, Ethiopia
}

\author{
Hailu Mosisa Chala (MSc) ${ }^{1} \quad$ Dr. Asfaw Kebede $(\mathrm{PhD})^{2}$ \\ 1.Water Resources \& Irrigation Engineering Dep't, Chiro Campus, Haramaya University; p.o box: 226, Chiro, \\ Ethiopia \\ 2.Haramaya Institute of Technology, Haramaya University; p.o box: 138, Dire Dawa, Ethiopia
}

\begin{abstract}
Accelerated soil erosion and sedimentation is a serious concern worldwide problem and the problem of sedimentation is clearly felt in the irrigation canals, in dry years when there is scarcity of rain more silt-laden water is diverted to the canals which cause high reduction of canal capacity discharge. Hirna watershed at which Hirna small scale irrigation project found is one of the most erosion-prone watersheds in the eastern highland of Ethiopia which little attention is given. The objectives of this study were to estimate Hirna river watershed sediment loss and to evaluate the design concept of Hirna small scale irrigation canals in view of water and sediment transport. This study spatial predict soil loss rate of the watershed using Geographic Information System, Revised Universal Soil Loss Equation was used to estimate potential soil loss. Based on the analysis, the mean and total annual soil loss potential of the study watershed was $26.61 \mathrm{ton} / \mathrm{ha} / \mathrm{yr}$ and 140,569.99 tons/yr respectively. About $36.60 \%$ $(1,933.42 \mathrm{ha})$ of watershed was classified under high to very high soil loss class while the remaining $63.40 \%$ ( 3349.17 ha) of watershed categorized under slow to moderate soil loss class. The total soil loss at the outlet of watershed or at the weir site estimated as $25,311.80$ tons. Beside spatial estimation of soil loss, field soil loss measurement by runoff controlling point was also done. The estimated mean annual soil loss from watershed with runoff pot method was $22.30 \mathrm{ton} / \mathrm{ha} / \mathrm{yr}$. which that the two value of soil loss estimated with runoff plot and spatial estimated with the help of the model was almost the same. Assessment of irrigation project and structural problem by measuring bed load, structural problem observation, and redesigning of the Hirna small scale irrigation were done to relate the capacity of the structure with the designed discharge and sediment deposited. As the assessment show the project have a problem of sedimentation due to improper design of flow velocity and canal slope. Finally the result show 116.80 tons of sediment was deposited in irrigation canal which have dramatically reduced the quantity of designed water depth into $41.67 \%$ and reduced designed discharge with $50.2 \%$.
\end{abstract}

Keywords: - GIS, RUSLE, hydraulic structure, Design, Hirna, Ethiopia

DOI: $10.7176 / \mathrm{ISDE} / 10-3-01$

Publication date:March $31^{\text {st }} 2019$

\section{INTRODUCTION}

Accelerated soil erosion and sedimentation is a serious concern worldwide, and it is difficult to assess its economic and environmental impacts accurately because of its extent, magnitude, rate, and complex processes associated with it (Lim, 2005). Soil erosion has accelerated on most of the world, especially in developing countries including Ethiopia, due to different socio-economic, demographic factors and limited resources (Bayramin et al, 2003). soil loss due to erosion of cultivated fields in Ethiopia amounts to about 42 metric tons $\mathrm{ha}^{-1} \mathrm{yr}^{-1}$. Therefore, it becomes a destructive process when it is exacerbated by a number of anthropogenic factors such as deforestation, overgrazing, incorrect methods of tillage and unscientific agricultural practices (Ayalew, G. 2014).

Soil loss is the amount of material that is actually removed from a particular slope. Due to the possible onsite deposition of soil materials due to changes in topography, vegetation, and soil characteristics, soil loss is usually less than soil erosion. Thus, sediment yield is used to refer to the amount of eroded material that is actually transported from a plot, field, channel, or watershed (Lim, 2005). In the last decades, soil erosion has been accelerated by human intervention through deforestation, over grazing and poor farming practices. Soil erosion is a wide spread problem causing soil and organic matter losses and hence loss of fertility and reduction in crop yields. In addition to these, on-site problems it also produces important off-site effects, like down stream sediment deposition in fields, flood plains of water bodies, water pollution, canal and reservoir siltation. It is therefore important to assemble quantitative data on the extent, magnitude and actual rates of erosion/sedimentation as well as on their economic and environmental consequences. As erosion and sedimentation are related problems, there are advantages in studying them simultaneously (Lim, 2005).

In the African highlands, erosion has occurred for a long time (Nyssen et al., 2004). In colonial times, the devastating effect of soil loss from newly developed agricultural lands was noted and the need to combat it was expressed. However, despite large investments in soil and water conservation practices, sediment yields have been increasing in Africa (Fleitmann et al., 2007). The reasons for increased soil loss were population pressure and 
consequently more intensive cultivation (Fleitmann et al., 2007). Due to greater population pressure and consequently more intensive cultivation, erosion losses have been increasing to an annual areal average of 7 ton/ha equivalent to depth $0.5 \mathrm{~mm}$ (Garzanti et al., 2006).In Ethiopia, the situation is even worse. Over centuries, deforestation, overgrazing, and practices such as cultivation on slopes which is not suited for agriculture, have eroded the soil. Moreover, as reported by Mitiku et al. (2006), 40\% of all erosion in Ethiopia is caused by the wrong installation of soil and water conservation (SWC) practices, clearly indicating that our understanding of erosion processes is far from perfect. The same as Bobe (2004) reported that one of the main factors contributing to severe soil degradation by accelerated soil erosion in Ethiopia is related to the ever-growing population pressure that led to shortage of arable lands and forced the farmers to clean and cultivate marginal area. Moreover, the lack of adequate land use policy added to the mountainous and rugged topography as well as erratic rainfall exacerbate the problem. In Ethiopian highlands, nearly $85 \%$ of the population depends on subsistence agriculture. One process that threatens the resource base is soil erosion. Studies have shown that in Ethiopia billions of tons of soil are lost annually (USDA, 2000). Local erosion rates are highly spatially variable ranging from less than 1 to over 400 tons/ha/year (Hurni, 1988; Mitiku et al., 2006); Tebebu et al., 2010).

In Ethiopia, soil erosion is a major challenge, posing a severe threat to the country's economy and development. The problem also extends to the downstream neighboring countries. The study of sediment transport is mainly focused on the sediment and erosion processes in irrigation canal networks. In view of maintenance activities the head works should be designed in such a way that they prevent or limit the entrance of sediment into canals. In addition, the design of the canal network should be based upon the transport of all the sediment to the fields or to specific places in the canal system, where the deposited sediment can be removed at minimum cost. Sedimentation should be prevented in canals and near structures, as it will hamper and endanger a correct irrigation management, the main objectives of which are to deliver irrigation water in an adequate, reliable, fair and efficient way to all the farmers at the required water level, at the right time and at the proper rate. Inadequate management will result in low efficiency and unnecessary loss of the already scarce resource (Herman D. et al., 2015).

The sediment transport aspect is a major factor in irrigation development as it determines to a large extent the sustainability of an irrigation scheme, particularly in case of unlined canals in alluvial soils. Investigations in this respect started since Kennedy published his channel forming discharge theory in 1895. Subsequently, different theories have been developed and are used around the world. All of them assume uniform and steady flow conditions and try to find the canal dimensions that are stable for a given discharge and sediment load. In the past irrigation schemes were designed for protective purposes with very little flow control, hence steady and uniform flow conditions could be realized to some extent (Ackers, 1993).

To effectively estimate soil erosion the Revised Universal Soil Loss Equation (RUSLE) has been used in many countries including Ethiopia. The rate of soil erosion is severe in the highlands of Ethiopia. Accelerated soil erosion by water has been a major threat to crop production in Ethiopia (Tamene, 2005). RUSLE adapted to Ethiopian conditions was used to estimate potential soil losses by utilizing information on rainfall erosivity (R) using interpolation of rainfall data, soil erodibility $(\mathrm{K})$ using soil map, vegetation cover $(\mathrm{C})$ using satellite images, topography (LS) using Digital Elevation Model (DEM) and conservation practices (P ) using satellite images (Ayalew, G. 2014).

Irrigation canals form a complicated hydraulic system as they have to handle the motion of water and sediment as well as the mutual interaction of both motions. Flowing water transports sediment, this sediment causes changes in the bed and on the sides of the canal, which also influences the water movement. Hence, sediment transport and water flow are interrelated and cannot be separated; since they influence each other in an implicit manner (Herman, D. et al., 2015).

The Universal Soil Loss Equation (USLE), in its original and modified forms, is the most widely used model to estimate soil loss from watersheds. That the various parameters of USLE can be derived from rainfall distribution, soil characteristics, topographic parameters, vegetative cover and information on conservation support (erosion control) practice are often available in the form of maps or can be mapped through collection of data from possible sources. Due to geographic nature of these factors USLE can easily be modeled into GIS. The USLE model applications in the grid environment with GIS would allow us to analyze soil erosion in much more detail since the process has a spatially distributed character. The GIS and Remote Sensing (RS) provide spatial input data to the model, while the Universal Soil Loss Equation (USLE) can be used to predict the sediment yield from the watershed (Vemu, and Pinnamaneni, 2012).

There are many challenges to optimize and to improve productivity of the existing irrigation system. One of the main challenges in this irrigated agriculture is a system performance which is not fulfilled its design capacity. There are many causes for this low performance e.g. damage on the canal which increases water losses through the leakages and sedimentation in the canal which reduces canal capacity. Hirna small scale irrigation is one of the strategic irrigation schemes in West Hararghe zone, where most of the structure have problem of sedimentation. The project is found at Tullo Woreda in which soil erosion is the major cause for sedimentation. Sedimentation is the core problem of the structure due to lack of regular maintenance. Sedimentation observed as the main problem 
on irrigation structure especially on canal, weir, sluice gate, sediment removing structures and other hydraulic structure. The general objective of this study is to estimate the watershed sediment loss and to evaluate the design concept of irrigation canals in view of water and sediment transport.

\section{The specific objectives are}

$>$ To examine the potential of the canals, with the rate of sediment accumulation

$>$ To determine the visibility of the soil loss and its cause

$>$ Redesign of irrigation canal with point view of sediment transport

\section{MATERIALS AND METHODS}

\subsection{Description of the Study Area}

\subsubsection{Location}

Laga Hirna small scale irrigation project cover 80 ha of agricultural land is found in West Hararghe Zone, Tullo district, covering two Keble $e^{e e}$ s of project areas, Lubo Dekeb and kere kufes PAs. The site of Laga Hirna project is $45 \mathrm{~km}$ from Chiro Town and $371 \mathrm{~km}$ from Addis Ababa. The scheme is found at $9010^{\text {ee }} 09.66^{\text {" to }} 9015^{\text {ee }} 54.0^{\prime \prime} \mathrm{N}$ latitude and $41001^{\text {ee }} 51.33$ " to $41015^{\text {ce }} 52.0$ " E longitudes with average elevation of 1822.75 m.a.s.l. which categorized under wet weyna dega Agro climatic zone.

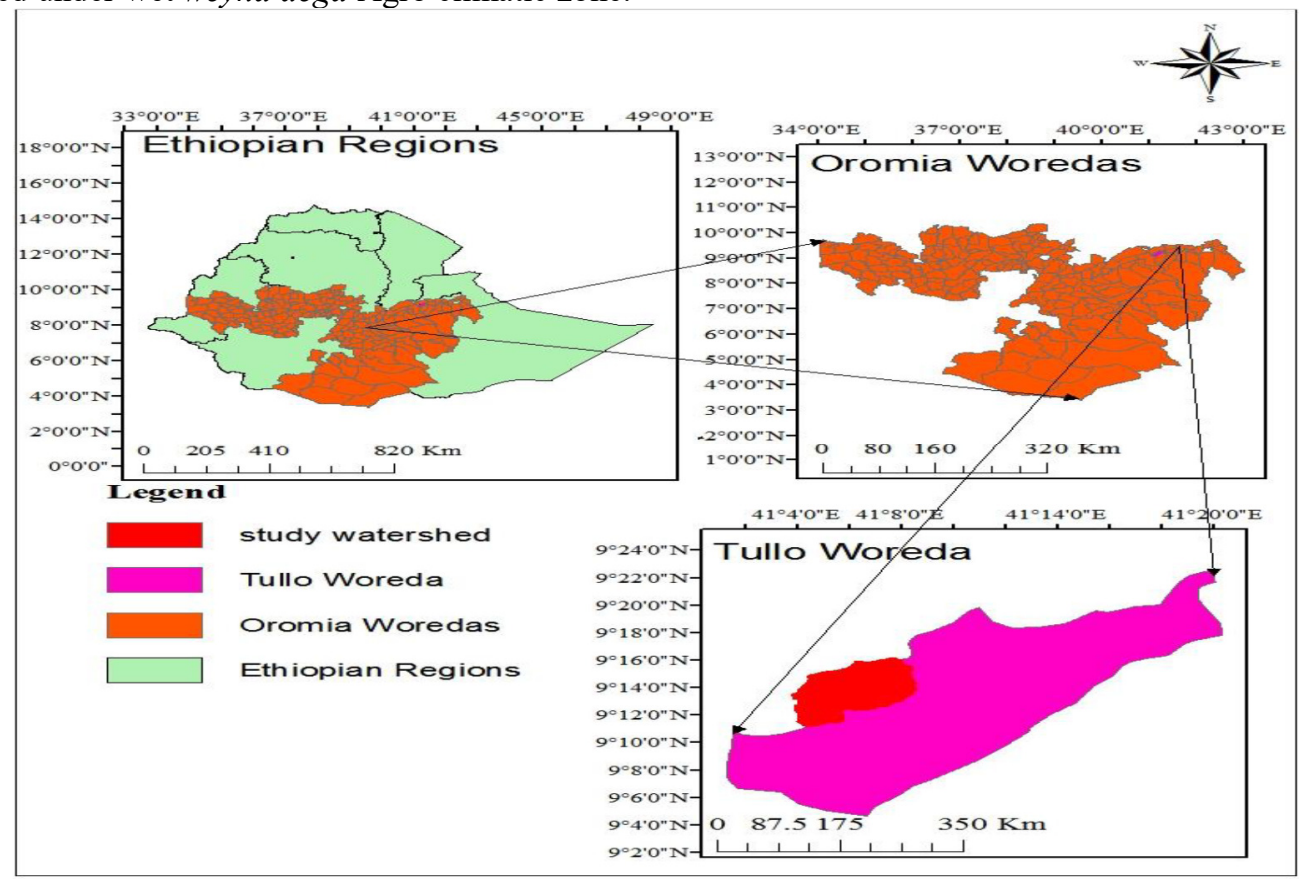

Figure 1. Map of the study area

\subsubsection{Climate}

Daily, monthly, and annual rainfall and temperature data were collected from Ethiopian Meteorological Agency for the years from 1992 to 2015.The mean annual rainfall of the project area is estimated as $1001 \mathrm{~mm}$. with Maximum monthly rain fall of $460 \mathrm{~mm}$ at august month and minimum monthly rain fall of $0 \mathrm{~mm}$ at January \& February months was recorded on the area. More than $90 \%$ of the rain occurs from June to September; July and August being the wettest months. The average maximum and minimum daily temperatures vary from $270 \mathrm{C}$ and $100 \mathrm{C}$ respectively. 


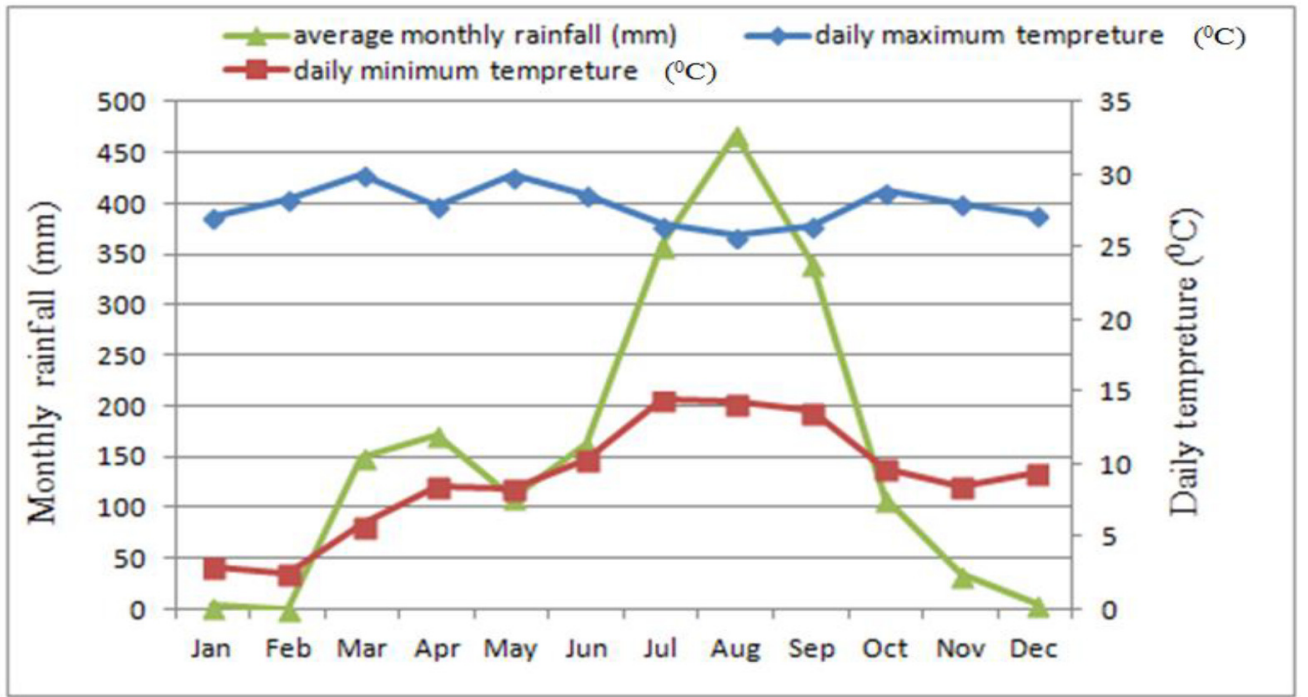

Figure 2. Monthly Rainfall and Average daily temperature of study area

\subsubsection{Topography}

The study area is a mountainous and highly trained with steep slopes characterized with steep slopes of $0-62.8 \%$ and elevation of the study area ranges from $1733-2,500 \mathrm{~m}$ above mean sea level. Most of the land in watershed characterized with mountainous surrounding the river. As the below contour figure show the watershed is characterized as gentle slope at the middle part around the outlet and steep slope at the boundary of the watershed.

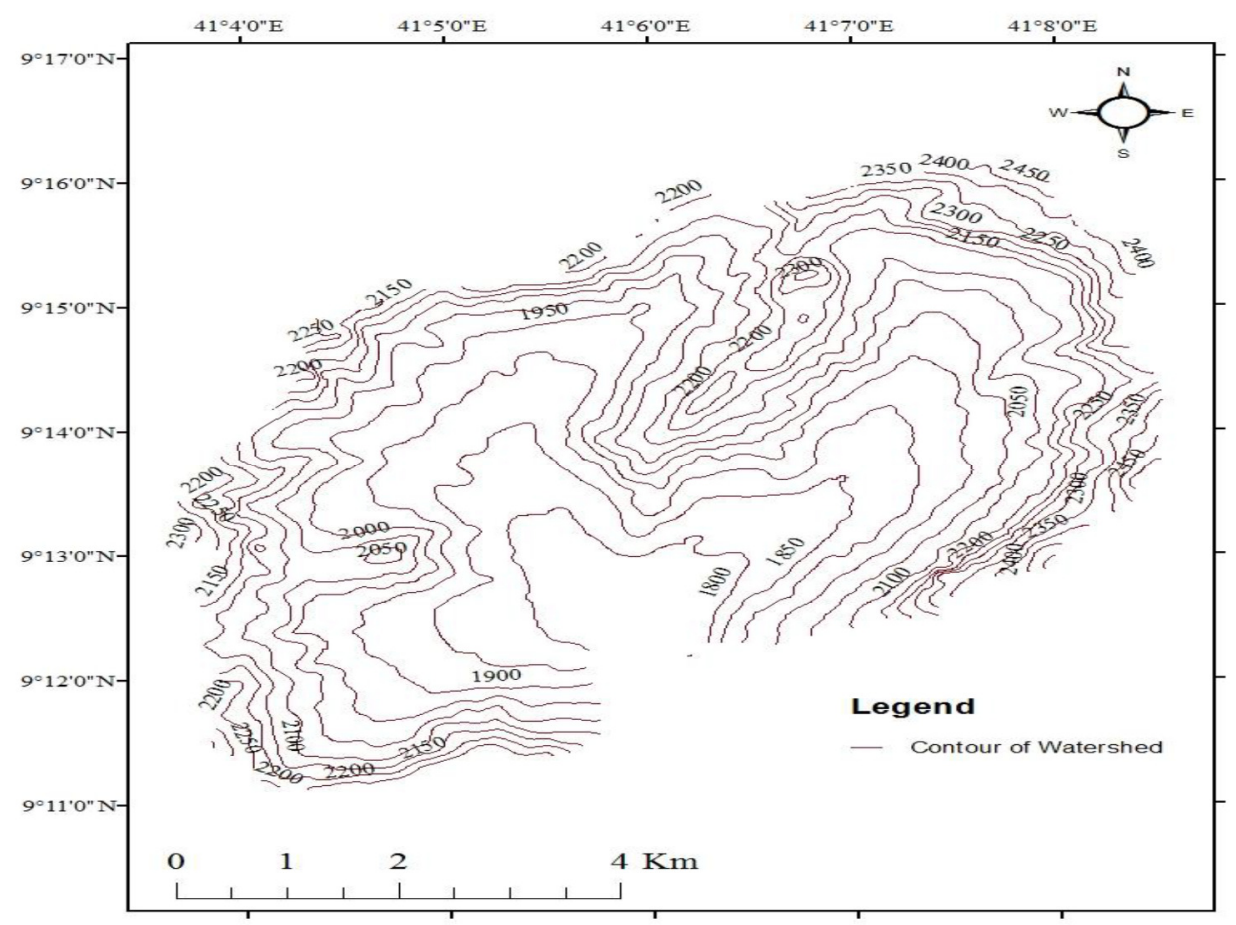

\subsubsection{Water resource and diversion structure}

Figure 3. Contour map of study watershed

The main source of water for Hirna small scale irrigation project is seasonal Hirna River and spring water. The spring water is located at $10 \mathrm{~m}$ from diversion structure. The existing diversion structure is located at the middle of Hirna River and has reasonable bank height and narrow width. At the diversion structure site the designed catchment area contributing high flood of about $30 \mathrm{~m}^{3} / \mathrm{sec}$ (Hirna Small Scale Irrigation Design Document 2010/2011). Nature of the farm land at the two sides of the river bank is located between small extended embankment sideways and thus same guide wall structure like dyke is recommended to keep river course shifting. The proposed diversion structure type is broad crested weir type; which needs a very high guide bank and providing 
an earthen fill bank or dyke is mandatory.

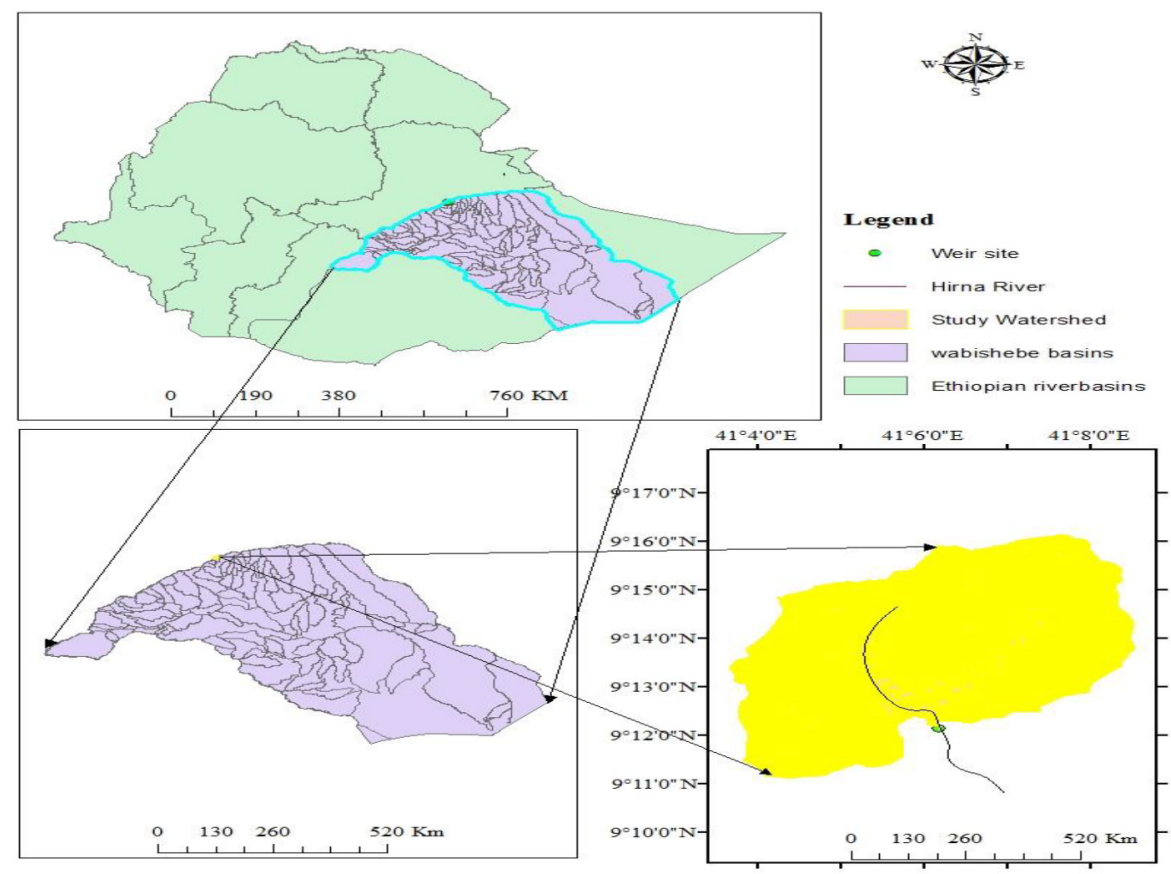

Figure 4. Hydrological location of Hirna River

\subsubsection{Demographic characteristics}

According to the information obtained from (West Hararghe Zone development agents data of 2010), in two PA's total of 1822 family heads are found. Where female head family account $15.4 \%$ while the rest are male headed. The total number of population is 8153 and female amount 4129 or $50.6 \%$, the average family size is 4.47 persons per households and also sex ratio is 102.6 female to 100 male. Largest ethnic group in the area is Oromo and the religion they follow is Islam (Tullo Woreda development agent document, 2010).

\subsubsection{Watershed of the project}

The total area of the watershed under the project is 5,282.6 ha. The watershed has fan shape with eight stream order and the rainfall formed has less time of concentration. Steams of watershed are highly contributing runoff that accelerate the soil erosion and peak runoff at the outlet of the watershed.

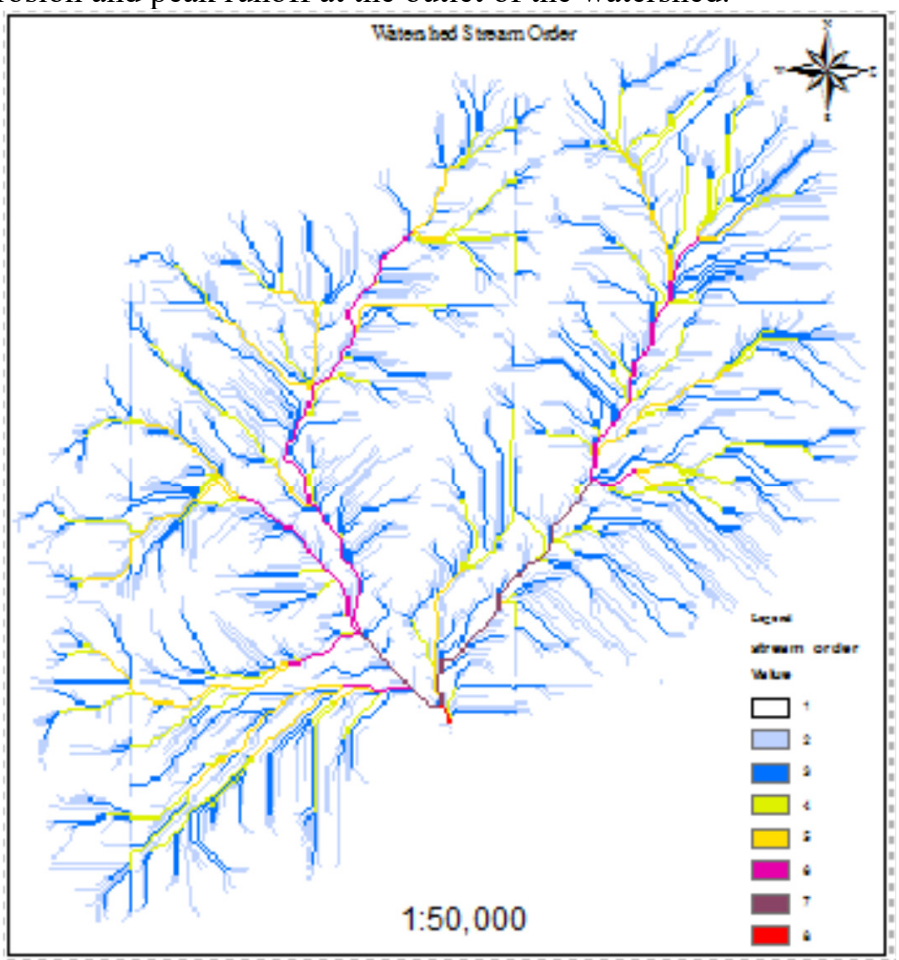

Figure 5. Watershed of the study area 


\subsection{Data collected}

In this study both primary and secondary data have been used.

\subsubsection{Primary data}

Primary data (soil loss using ground control points, canal bed load, canal water depth, soil texture, particle size and dry bulk density by soil sampling) were collected. Field observations were carried out to collect ground control points (GCP) for image classification and soil loss vulnerability verification.

\subsubsection{Secondary data}

Secondary data such as monthly climatic data for 24 years (1992 to 2015) from national metrological agency (NMA), Satellite image (Landsat8, 2015) (LDCM), topographic map (west Hararghe Zone Irrigation Agency Bureau), soil data created by MoWIE Oromia Regional digital Soil map at 1:150,000 scale from Ministry of Water, Irrigation and Energy (MoWIE in 2014) were collected. In addition to this, focus group discussion/ interview at house hold were done to know the visibility of soil loss and its impact on irrigation structure.

\subsection{Data preparation}

\subsubsection{Estimation of missed rainfall data}

Estimation of missed data values of station is often desirable $p$ to use the data. In this study, the data for base station or Hirna metrological station was missed for three years. XLSTAT tools (nearest neighbor estimation method) used to complete missed data. Most XLSTAT functions include options to handle missing data. However, only few approaches are available. This tool allows completing or cleaning dataset using advanced missing value treatment methods using the nearest neighbor station (Allison, 2001).

\subsubsection{Consistency and homogeneity of meteorological data}

The data consistency of the given metrological stations was cheeked with the help of double mass-curve method with in reference to their neighborhood stations. The double mass curve was plotted by using the annual cumulative total rainfall of the base station (Hirna station) as ordinate and the average annual cumulative total of neighboring stations as abscissa.

The homogeneity of annual rainfall of study area station was tested using XLSTAT 2016 software SNHT test (Alexanderson, 1986). The SNHT test (Standard Normal Homogeneity Test) was developed by Alexanderson (1986) to detect a change in a series of rainfall data. The test is applied to a series of ratios that compare the observations of a measuring station with the average of several stations. The ratios are then standardized. The series of $\mathrm{X}_{\mathrm{i}}$ corresponds here to the standardized ratios. The null and alternative hypotheses are determined by: H0:- The T variables Xi follow a $\mathrm{N}(0,1)$ distribution.

Ha: - Between times 1 and $v$ the variables follow an $\mathrm{N}\left(\mu_{1}, 1\right)$ distribution, and between $v+1$ and $\mathrm{T}$ they follow an $\mathrm{N}\left(\mu_{2}, 1\right)$ distribution.

$$
\begin{aligned}
& \mathrm{T}_{\mathrm{O}}=\max \quad 1<z<T\left(v Z_{1}^{2}+(n-v) z_{2}^{2}\right) \\
& \text { with } \\
& Z_{1}=\frac{1}{v} \sum_{t=1}^{v} x_{t} \\
& Z_{2}=\frac{1}{n-v} \sum_{t=v+1}^{T} x_{i}
\end{aligned}
$$

The To statistic derives from a calculation comparing the likelihood of the two alternative models. The model corresponding to $\mathrm{Ha}$ implies that $i 1$ and $\mathrm{i} 2$ are estimated while determining the $\mathrm{n}$ parameter maximizing the likelihood.

XLSTAT evaluates the p-value and an interval around the p-value by using a Monte Carlo method.

$\mathrm{T}=$ is successive times

\subsubsection{Digital Elevation Model}

DEM (Digital Elevation Model) represents the spatial distribution of elevation of the surface in digital format. DEM has become vital input for automated generation of terrain and hydrologic features. It is the source for generation of terrain features like slope, aspect, hill shade, and other relief features. It has also some hydrologic application for watersheds such as determining flow direction, flow accumulation, stream-order, stream length, watersheds, Basins etc. DEM is also vital input for soil erosion modeling. For the study, the modified LS-factor map was generated from the slope and flow accumulation map derived from the DEM. To create DEM of the study area contour map was digitized from the topographic maps of 1:60,000 scale with contour interval of $30 \mathrm{~m}$. 


\subsection{Data Analysis}

Data analysis with GIS includes generation of watershed; generation of R, K, LS, C and P and reclassification of derived datasets. Digital image processing, preprocessing of satellite image data, masking the image with the watershed boundary; earth resources data analysis system (ERDAS 10) software was used for land use land cover class. Data analysis and processing were made by digitizing, calculating and classifying the necessary information of each layer with the help of ArcGIS 10.1 software and RUSLE model. Furthermore, some simple statistical methods, such as percentage, average and graphic tabulation were also employed for the analysis and interpretations as it has shown under below sections.

\subsubsection{Soil erosion estimation using-RUSLE}

The basic methodological approach followed in RUSLE has been detailed in the following simplified flow chart in which all the variables combine together to develop the RUSLE model.

\subsubsection{Land use and land cover factor (C_factor)}

A land-use and land-cover of the study area was prepared from Land-sat 8 image (LDCM) (path 167 row 054 ) acquired on 12 February 2015 was trained and processed with watershed in ERDAS Imagine 10 software to extract the different landforms of the study area. The extracted data generates LULC map which was checked and completed through field observation and with the help of Google earth. Supervised image classifications technique was done, land use and land cover types where identified. The land use land cover classified changed to grid form and a corresponding C_value obtained from (Hurni, 1988, Eweg and van Lammeren, 1996, BCEOM, 1998, Wischmeier and Smith, 1978) was assigned in a GIS 10.1 environment.

Table 1. Land use and land cover (C_value) used in different studies.

\begin{tabular}{lll}
\hline Land-use and land-cover type & C factor value & References \\
\hline Forest & 0.02 & Hurni (1988) \\
Grassland & 0.01 & Eweg and van Lammeren (1996) \\
Cultivated land (cereals/pulses) & 0.17 & Hurni (1988) \\
Bare land & 0.60 & BCEOM (1998) \\
Shrub & 0.014 & Wischmeier and Smith (1978) \\
\hline
\end{tabular}

\subsubsection{Management practice factor (P-value)}

The conservation practices factor $(\mathrm{P})$ reflects the effects of practices that will reduce the amount and rates of the water runoff and thus reduce the amount of erosion. Conservation measure implemented and mapping of conserved areas were used to quantify it. The P-value ranges from 0-1 depending on the soil management activities employed in the specific plot of land. The data related to management or support practices of the watershed were tried to collect during the field work. But, management or support practices are not practiced in the area. Therefore, since data were lacking on permanent management factors and there were no management practices, the $\mathrm{P}$ value suggested by Bewket and Teferi (2009), Wischmeir and Smith (1978), Hurni (1985), Shi et al. (2002) and Shiferaw (2011): that considered only two types of land uses (agricultural and other land/non-agricultural) and land slopes adopted for Ethiopian condition were used. The agricultural land areas were classified into six slope categories and assigned $\mathrm{P}_{-}$value; while non-agricultural land was assigned a $\mathrm{P}_{-}$value of 1.00 . A corresponding $\mathrm{P}_{-}$value was assigned to agricultural and non-agricultural land by using the re-class method in Arc GIS 10.1.

Table 2. Conservation practices factor ( $P$ value) based on slope and land use

\begin{tabular}{lll}
\hline Land use type & Slope (\%) & P-factor \\
\hline Agricultural land & $0-5$ & 0.11 \\
& $5-10$ & 0.12 \\
$10-20$ & 0.14 \\
& $20-30$ & 0.22 \\
& $30-50$ & 0.31 \\
Other land All & $50-100$ & 0.43 \\
All & 1.00
\end{tabular}

Source: Adopted from Wischmeir and smith (1978); Hurni (1985); Shi et al (2002); (Bewket and Teferi, 2009); (Shiferaw, 2011)

\subsubsection{Soil erodibility factor (K-factor)}

The erodibility of a soil is an expression of its inherent resistance to particle detachment and transport by rainfall. It is the result of the cohesive force between the soil particles and may vary depending on the presence or absence of plant cover, the soil "es water content and the development of its structure (Ayalew, 2015). The soil erodibility factor (K) represents the effect of soil properties and soil profile characteristics on soil loss (Renard et al, 1997). The principal factor affecting $\mathrm{K}_{-}$value are texture, structure, organic matter and permeability are also important contributors (Robert and Hilborn, 2000).

The soil data was collected from MoWIE of Oromia Regional state digital Soil map and Spatial Analyst Tool in GIS environment was used to obtain soil units map of the study watershed. Depending on digitalized developed soil map, five soil samples using auger were collected from different locations representing soil type to analyze 
texture, organic matter, permeability, at soil laboratory and structure at field identification. The sampling locations were identified based on the area proportion or area coverage of soil type. As identified on section 3.3.3 the value of $\mathrm{K}$ ranges from 0 to 1 . The developed RUSLE for Ethiopian condition proposed the $\mathrm{K}$ values of the soil based on their group as given in Table 3.

Table 3. Dominant soil types considered and the corresponding $K$ factor used for the initial calibration of the model

\begin{tabular}{llll}
\hline Soil types & Suggested K factor ranges & Soil types & Suggested K factor ranges \\
\hline Alisols & $0.30-0.40$ & Arenosols & $0.30-0.40$ \\
Andosols & $0.10-0.20$ & Chernozems & $0.10-0.20$ \\
Calcisols & $0.30-0.40$ & Cambisols & $0.15-0.25$ \\
Fluvisols & $0.15-0.30$ & Gypsisols & $0.30-0.40$ \\
Leptosols & $0.15-0.25$ & Luvisols & $0.20-0.30$ \\
Lixisols & & $0.20-0.30$ & \\
\hline Sour & &
\end{tabular}

Source: - (Hurni 1985)

The soil erodibility (K-factor) for the watershed was adapted based on soil unit types from (Hurni 1985) depending on the soil class of watershed, then the soil data with $\mathrm{K}$-factor added to GIS 10.1 to create Tin, Finally, the resulting shape file was changed to raster with a cell size of $30 \mathrm{~m}$ x $30 \mathrm{~m}$. The raster map was reclassified based on their type and the $\mathrm{K}$ value corresponds to erodibility value were created.

\subsubsection{Rainfall erosivity factor for $R U S L E$ model ( $R$ factor)}

Soil loss highly accelerated with rainfall through the detaching power of raindrops striking the soil surface and through the contribution of rain to runoff (Morgan, 1994). Morgan (1994), Wischmeier and Smith (1958) and later on Hudson (1965) and others obtained an equation to identify the kinetic energy and rainfall intensity for different regions.

The monthly rainfall, for the watershed was collected from five neighbors ${ }^{\text {ee }}$ metrological station (Chiro, Machara, Hirna, Gelamso, and Chelanko) from National Meteorological Service Agency (NMSA, 2015). Monthly rainfall records of the stations for 24 years from 1992 to 2015 were used to calculate the rainfall erosivity factor (R-value). The mean annual rainfall was first interpolated to generate continuous rainfall data from each station for each grid cell by “3D Analyst Tools Raster Kriging Interpolation” in ArcGIS 10.1 environment after necessary missed data were estimated.

The erosivity factor R was calculated according to the equation given by Hurni (1985), derived from a spatial regression analysis (Hellden, 1987) for Ethiopian conditions based on the available mean annual rainfall (p) (Equation 2.2).

$\mathrm{R}=-8.12+0.562 * \mathrm{P}$

where

$\mathrm{R}$ Rainfall erosivity, $\mathrm{P}$ the mean annual rainfall in $\mathrm{mm}$

\subsubsection{Slope length and steepness factor for RUSLE model (LS_factor)}

Topography is one of the factors accelerating soil loss and its influence on erosion is complex. The slope length ( $\mathrm{L}_{-}$factor) describes the distance between the origin and termination of inter-rill processes. Termination is either the result of the initiation of depositional processes or the concentration of flow into rills (Wischmeier and Smith, 1978). The slope gradient ( $L_{-}$factor) influences flow velocity and thus the rate of erosion.

The slope length factor and slope degree factors are typically combined together and defined as the topographic factor in RUSLE that is a function of both slope steepness and length of the land as expressed by (Wischmeier and Smith, 1978). The slope length and slope steepness were computed from DEM 30 m (Figure 13, at section 3.2.3) resolution using ArcGIS. Slope length and slope steepness were multiplied by using "Spatial Analyst Tool Map Algebra Raster Calculator" in Arc GIS 10.1 environment to calculate and map the slope length steepness factor (LS_factor) as shown in Equation (2.3) and defined by Wischmeier and Smith (1978) as cited by Ayalew (2015).

Slope Length (L_factor)

Using raster calculator in ArcGIS 10.1, value of $\mathrm{L}$ was determined using the following expression.

$\mathrm{L}=(\mathrm{POW}\{$ flow acc $\}+900,(\{\mathrm{~m}\}+1))-(\mathrm{POW}\{$ flow acc $\},\{\mathrm{m}\}+1)) /(\mathrm{POW}(30,\{\mathrm{~m}\}+2) \times$ pow $(22.13,\{\mathrm{~m}\}))$

\section{Slope Steepness (S_factor)}

In ArcGIS 10.1, value of $\mathrm{S}$ was determined using the following expression:

$\mathrm{S}=\operatorname{con}(\tan (\{$ slope $\} \times 0.01745)<0.09,(10.8 \times \sin (\{$ slope $\} \times 0.01745)+0.03),(16.8 \times \sin (\{$ slope $\} \times 0.01745)-$ $0.5))$

The value of $\mathrm{m}$ varies from 0.2 to 0.5 depending on the slope as shown in Table 5 (Wischmeier and Smith, 1978). 
Table 4. M_value

\begin{tabular}{ll}
\hline m-value & Slope (\%) \\
\hline 0.5 & $>5$ \\
0.4 & $3-5$ \\
0.3 & $1-3$ \\
0.2 & $<1$
\end{tabular}

Final the value of $\mathrm{L}$ and $\mathrm{S}$ determined for each grid cell, the LS factor was then determined by multiplying the $\mathrm{L}$ and $\mathrm{S}$ value in ArcGIS 10.1 and a map of the LS factor was produced

\subsubsection{Soil loss analysis}

Annual soil loss rate was determined by using RUSLE factor values ( $R, K, L S, C$ and $P$ ) in GIS environment "Spatial Analyst Tool, Map Algebra and Raster Calculator" in ArcGIS 10.1 software as shown in Equation 2.5. For the purpose of identifying priority areas for conservation planning, soil loss potential of the watershed was then categorized in to different severity classes following FAO and UNEP guideline, (1984), (Section 3.4; Table 9).

$\mathrm{A}=\mathrm{LS} * \mathrm{R} * \mathrm{~K} * \mathrm{C} * \mathrm{P}$

where

A - is the annual soil loss (ton $\mathrm{ha}^{-1}$ year $\left.^{-1}\right)$;

$\mathrm{R}$ - is the rainfall erosivity factor $\left[\mathrm{MJ} \mathrm{mm} \mathrm{h}^{-1} \mathrm{ha}^{-1} \mathrm{year}^{-1}\right]$;

$\mathrm{K}$ - is soil erodibility factor [ton ha h ha ${ }^{-1} \mathrm{MJ}^{-1} \mathrm{~mm}^{-1}$;

LS - is slope length factor (dimensionless);

$\mathrm{C}$ - is land cover and management factor (dimensionless); and

$\mathrm{P}$ - is conservation practice factor (dimensionless).

\subsubsection{Analysis of soil characteristics}

Five disturbed soil samples at $\left(0 \_15 \mathrm{~cm}\right)$ were taken from the four land use, land cover of the watershed, which two samples were from bare land to determine soil textural class, organic matter content, structure and soil permeability to identify the characteristics of the soil as well as for $\mathrm{K}$ _factor identification. The soil character create the soil erodibility us below equation

$$
\mathrm{K}=\frac{(\mathrm{Kt} * \mathrm{Km})+(\mathrm{Ks}+\mathrm{Kp})}{100}
$$

where

$\mathrm{K}$ - Soil erodibility

$\mathrm{Kt}$ - soil texture sub-factor

Ko - soil organic matter sub-factor

Ks - Soil structure sub-factor

$\mathrm{Kp}$ - soil profile permeability sub-factor

This all factors were identified as below equation

$$
\mathrm{Kt}=\frac{2.1[(\mathrm{Pls}+\mathrm{Pvfs}) *(100-\mathrm{Pcl})]^{1.14}}{10,000}
$$

where

Pls - percentage of silt

Pvfs - percentage of very fine sand

Pcl - percentage of clay soil

$\mathrm{Ko}=(12-\mathrm{Om})$

where

Om - Percentage of inherent soil organic matter

$\mathrm{Ks}=3.25(\mathrm{Ss}-2)$

where

Ss - Soil structure class

$\mathrm{Kp}=2.5(\mathrm{Pr}-3)$

where

Pr - soil profile permeability rating 


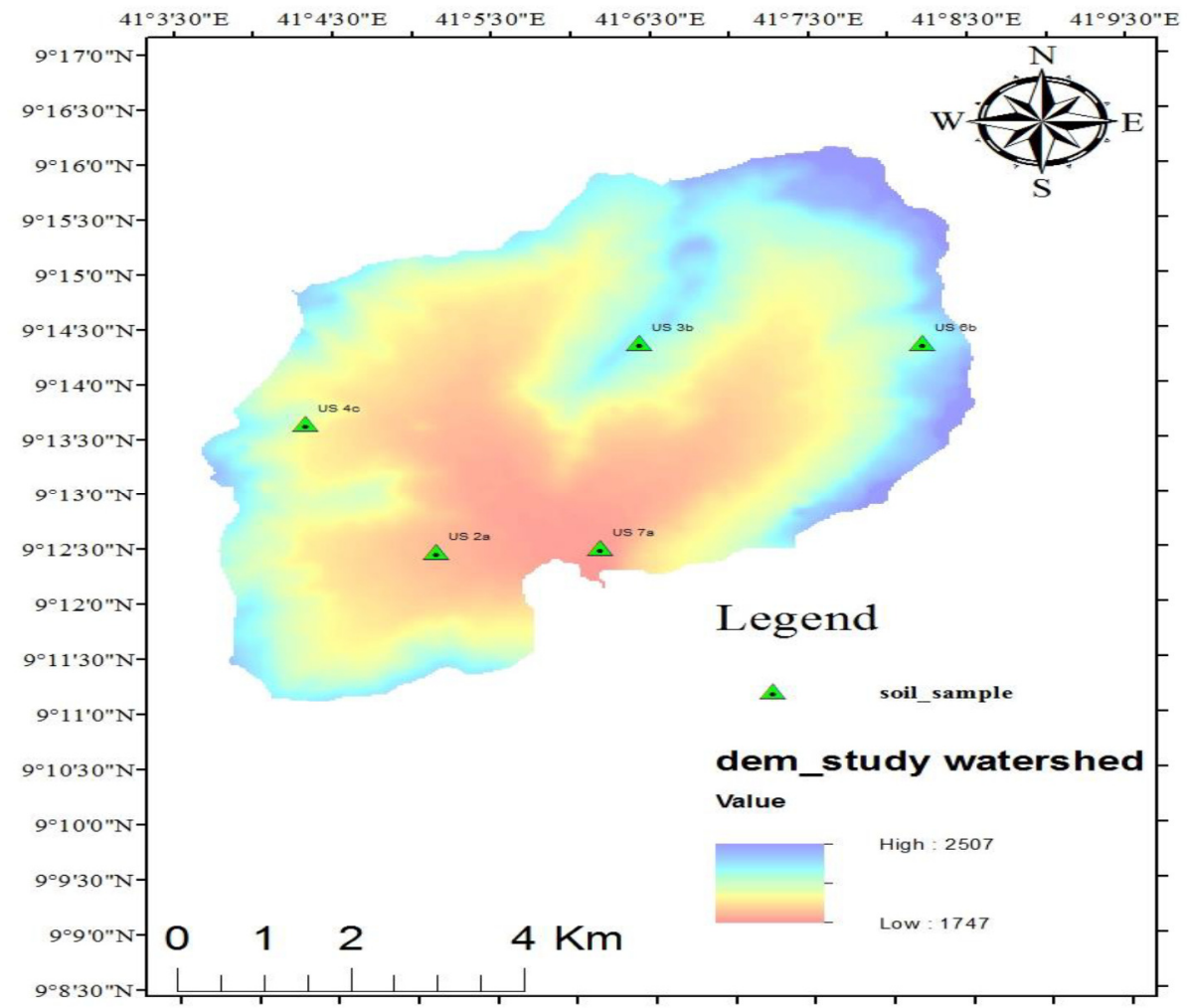

Figure 6. Soil sampling positions

The soil samples taken were dried in air and big lumps were crushed with an aid of motor and pestle. Then it was passed into a $2 \mathrm{~mm}$ sieve and stored in polythene bags for final analysis. Hydrometer method was used for analyzing the soil texture. 50 grams of $2 \mathrm{~mm}$ sieved soil samples were weighed into a polythene bottle. Soil texture was determined at laboratory and the textural classes of watershed were represented on the soil textural triangle.

Soil structure was determined by soil visual descriptors methods suggested by Shepherd (2000). To analyze permeability, undisturbed soil sample by core sampler from the field was taken. Subsequently, permeability was computed using laboratory method (constant head test method) proposed by Klute (1965). Organic carbon was determined by Walkely and Black method (Bernard et al., 1993). The organic matter was calculated by multiplying the organic carbon by a factor of 1.724. The value of soil characteristics were written under Appendix Table 3 and Appendix Table 4.

\subsubsection{Analysis of soil dry bulk density}

Undisturbed soil sample were taken from different land use, land cover and elevation to test soil dry bulk density with core sampler. Bulk density of the soil was determined at $0-15 \mathrm{~cm}$, depths. The samples were dried in an oven at $105^{\circ} \mathrm{C}$ for $24 \mathrm{hr}$ to a constant weight to estimate the moisture contained in the samples (Table 7 of section 3.1.2). The weight of the soil per unit volume was calculated from the known volume of the core sampler. It is expressed as follows:

$$
\rho_{\mathrm{D}}=\frac{M_{S}}{V_{t}}
$$

where:

$\rho$ is bulk density $\left(\mathrm{g} / \mathrm{cm}^{3}\right)$, Ms_is mass of oven dry soil core $(\mathrm{g})$ and $\mathrm{Vt}$ _ is volume of soil core $\left(\mathrm{cm}^{3}\right)$

\subsubsection{Sediment yield}

The sediment yields at the outlet of watershed were carried by the empirical equations below (Julien, 1998) (Equation 2.11)

$\mathrm{Sy}=\mathrm{E}^{*}\left(1 / \mathrm{A}^{0.2}\right)$

where,

Sy $=$ Sediment yield (ton) at the watershed out let;

$\mathrm{E}=$ total erosion (ton);

$\mathrm{A}=$ watershed area (ha)

\subsubsection{Field measurement of watershed soil loss}

Runoff and sediment data were collected by runoff plot method at one controlling point in the watershed which 
used for checking and validation of the results obtained by RUSLE. The data of soil loss were collected during rainy season. Runoff sediment collection was installed nearest to the watershed outlet to take soil loss by rainfall of $24 \mathrm{hr}$ from agricultural field; each day sediment coming from rectangular field of $(6 \mathrm{~m} \mathrm{x} 8 \mathrm{~m})$ sample area were collected in barrel and measured. One third of the soil loss from the field made to enter into the control point and daily soil loss depth were collected. Finally the total soil losses from the plot were converted to the watershed area soil loss (Equation 2.12).

$\mathrm{V}_{\text {Soil }}=\left(\Pi \mathrm{R}^{2} \mathrm{H}\right)\left(\mathrm{cm}^{3}\right)$

Where

$\mathrm{V}_{\text {Soil }}=$ volume of soil loss measured from control point (sample area).

$\mathrm{R}=$ radius of barrel

$\mathrm{H}=$ depth of soil collected.

\subsubsection{Assessing of the project design document}

Major constraints of Hirna small scale irrigation scheme design, construction, operation and maintenance of the structures and lack of monitoring and evaluation activities were assessed in order to relate them to sedimentation and other structural problems. These were done by detail reviewing of the design document of Hirna small scale irrigation scheme from west Hararghe water and irrigation office such as hydrology, geology, headwork and infrastructure and physical observation of the scheme. Finally, redesigning of the structure were done to identify if the design of the structure considering the problem or not by using Lacey equation, with Manning equation.

Redesign of the project were done to identify if the design concept consider the sediment problem that means if the canal design consider the sediment problem and potential of the canal to transport both the deposited sediment and the required discharge to the command area.

\subsubsection{Estimation of canal bed load}

Depth of sediment deposited sample was taken at upstream, middle, and downstream of the canal along the horizontal cross-section. Totally 63 sample of sediment at a depth of the canal were taken with an interval of 50 $\mathrm{m}$.

The sediment volume $(\mathrm{SV})\left(\mathrm{m}^{3}\right)$ was computed by taking the depth $(\mathrm{m})$ and cross sectional area $(\mathrm{A})\left(\mathrm{m}^{2}\right)(\mathrm{SV}$ $=$ area $*$ depth). The volume of the silt was converted to sediment yield (in mass bases) by multiplying silt volume and dry bulk density $(S Y=S V * d B D)$. Finally, the specific sediment yield (SSY) was calculated by dividing sediment yield to catchment area.

$(\mathrm{SSY}=S Y / A)$

where

$\mathrm{SV}$ - is sediment volume $\left(\mathrm{m}^{3}\right)$;

$\mathrm{SY}$ - is sediment yield ( $\left(\right.$ on $\left.\mathrm{yr}^{-1}\right)$;

$\mathrm{dBD}$ - is dry bulk density (ton $\mathrm{m}^{-3}$ );

SSY - is specific Sediment Yield (ton $\mathrm{km}^{-2} \mathrm{yr}^{-1}$ ) and

A - is catchment area $\left(\mathrm{km}^{2}\right)$.
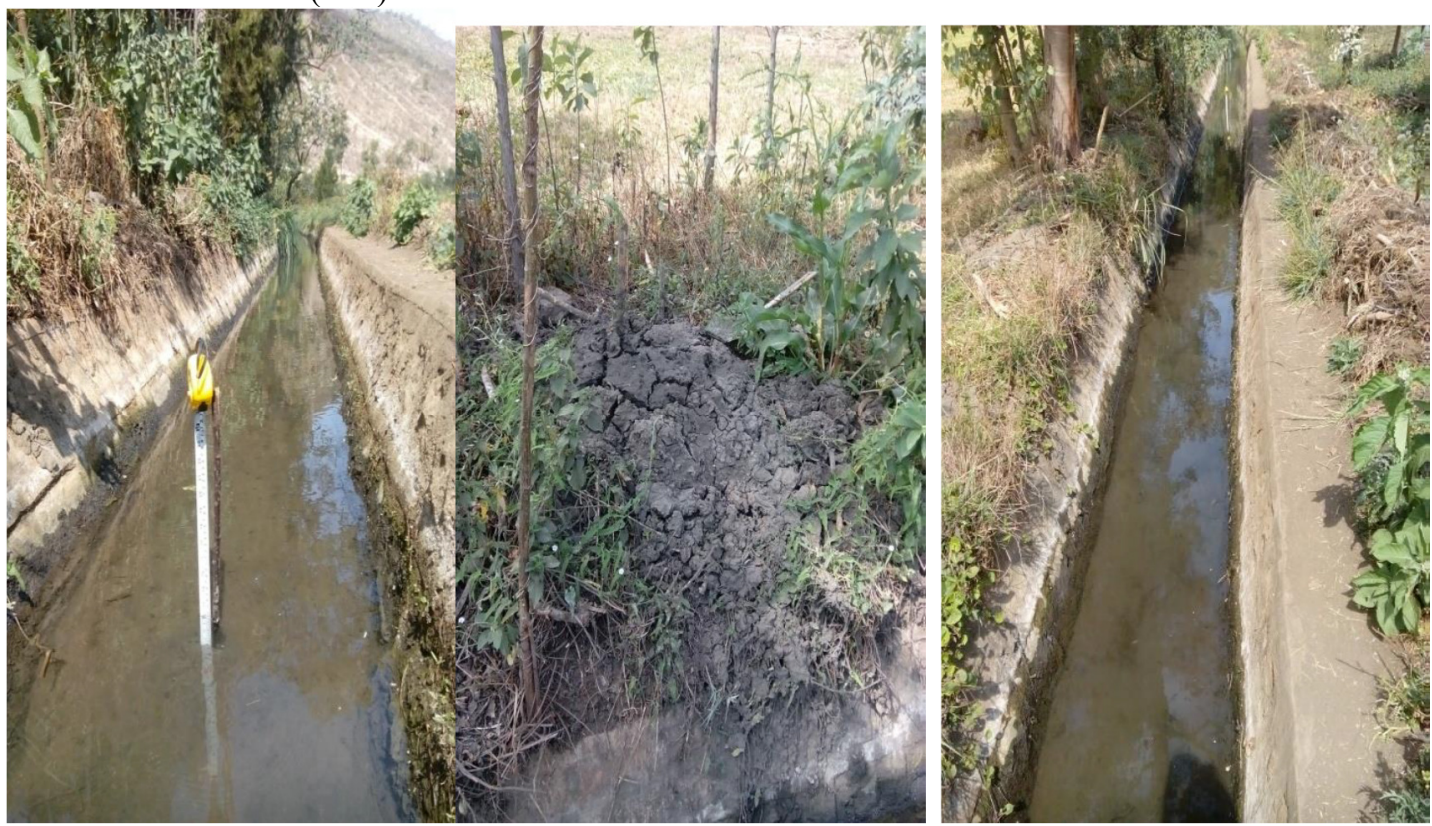

Figure 7. Measuring depth of sediment deposited in canal 


\section{RESULTS AND DISCUSSION}

In this section, major findings of the study including characterization of watershed soil loss, spatial analysis of the watershed characteristics, land use land cover, soil loss management practice, and hydraulic structure assessment of the project are presented.

\subsection{Physical Characteristics of the Watershed}

\subsubsection{Land use and land cover of watershed}

The major land use and land cover class of the study watershed are bare land, forest, cultivated, and settlement lands. Most part of the watershed, $75.10 \%$ is bare land and the remaining land feature cover $24.90 \%$ of the total land as shown in Table 5.

The study area is mountains and steeper slope at the upper stream of watershed which is bare land. While forest lands were dispersed around the cultivated flat land area through the watershed (Figure 9).

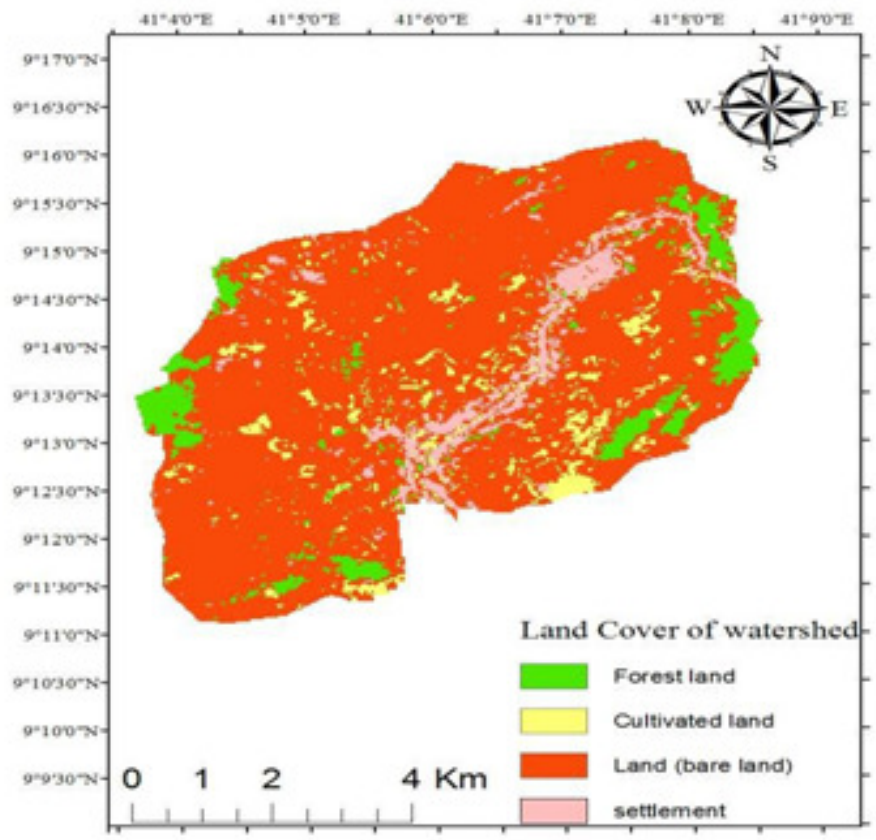

Figure 8. Land use and land cover of watershed (LDCM)

Table 5. Land use and land cover of watershed

$\begin{array}{cccc}\text { No } & \text { Land cover type } & \text { Area coverage(m2) } & \text { Percentage (\%) } \\ 1 & \text { Forest land } & 3,063,908 & 5.80 \\ 2 & \text { Cultivated land } & 6,413,076.4 & 12.14 \\ 3 & \text { Settlement } & 3,676,689.6 & 6.96 \\ 4 & \text { Bare land } & 39,672,326 & 75.10 \\ & \text { Total } & \mathbf{5 2 , 8 2 5 , 7 7 9} & \mathbf{1 0 0}\end{array}$

\subsubsection{Soil of study watershed}

The watershed dominated by Eutric leptosols soil type which covers $90.96 \%$ and Haplic Luvisols which cover $9.04 \%$ of watershed area. 


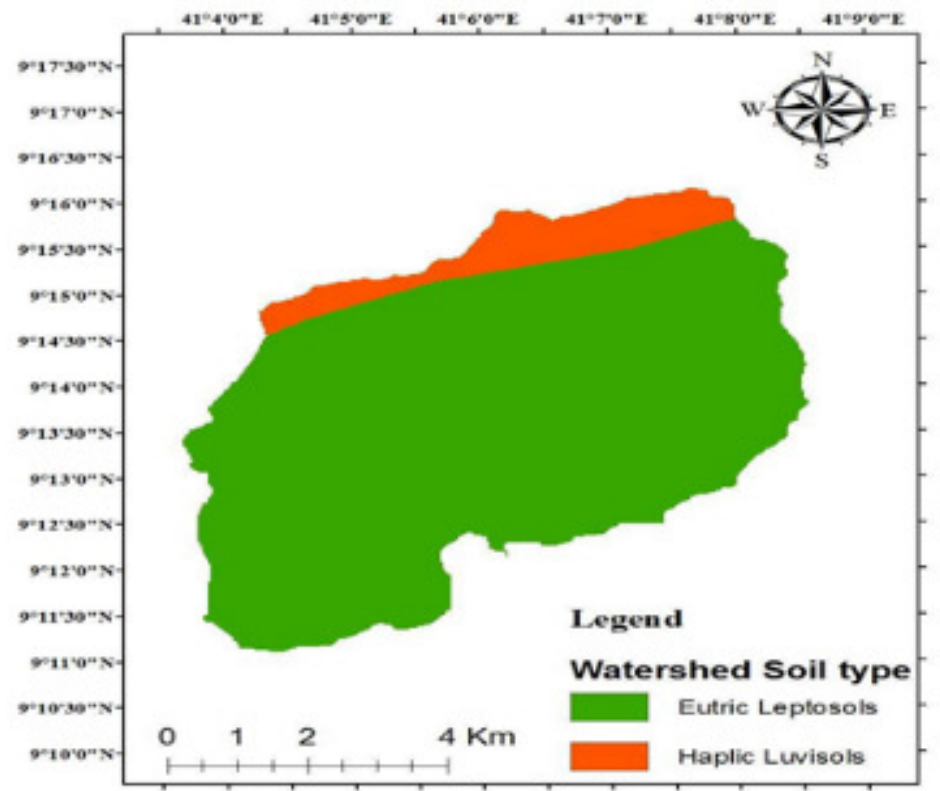

Figure 9. Major soil type of study watershed

\subsection{Data Preparation}

\subsubsection{Estimation of missed rainfall data}

Inadequate and missed rainfall data for accurate measurement input was considered and estimated depending on the neighbor mean annual precipitation. The base station or Hirna station has missed data for year 2005, 2006 and 2007. The missed values were filled using XLSTAT tools (section 2.3.1.) and the results were written under Appendix Table 6.

\subsubsection{Consistency analysis and homogeneity test}

The double mass curve was plotted for annual cumulative total rainfall data of the base station

(Hirna) with the average annual cumulative data of neighborhood station (Chiro, Mechara, Gelamso and Chelanko). The graph of the double mass curve plot was found to be almost linear for base metrological station with coefficient of determination $\left(\mathrm{R}^{2}\right) 0.99$ which is 1.0 as shown in Figure 11. This implies that the rainfall data was consistent over the considered period of rainfall data.

\section{Double Mass curve}

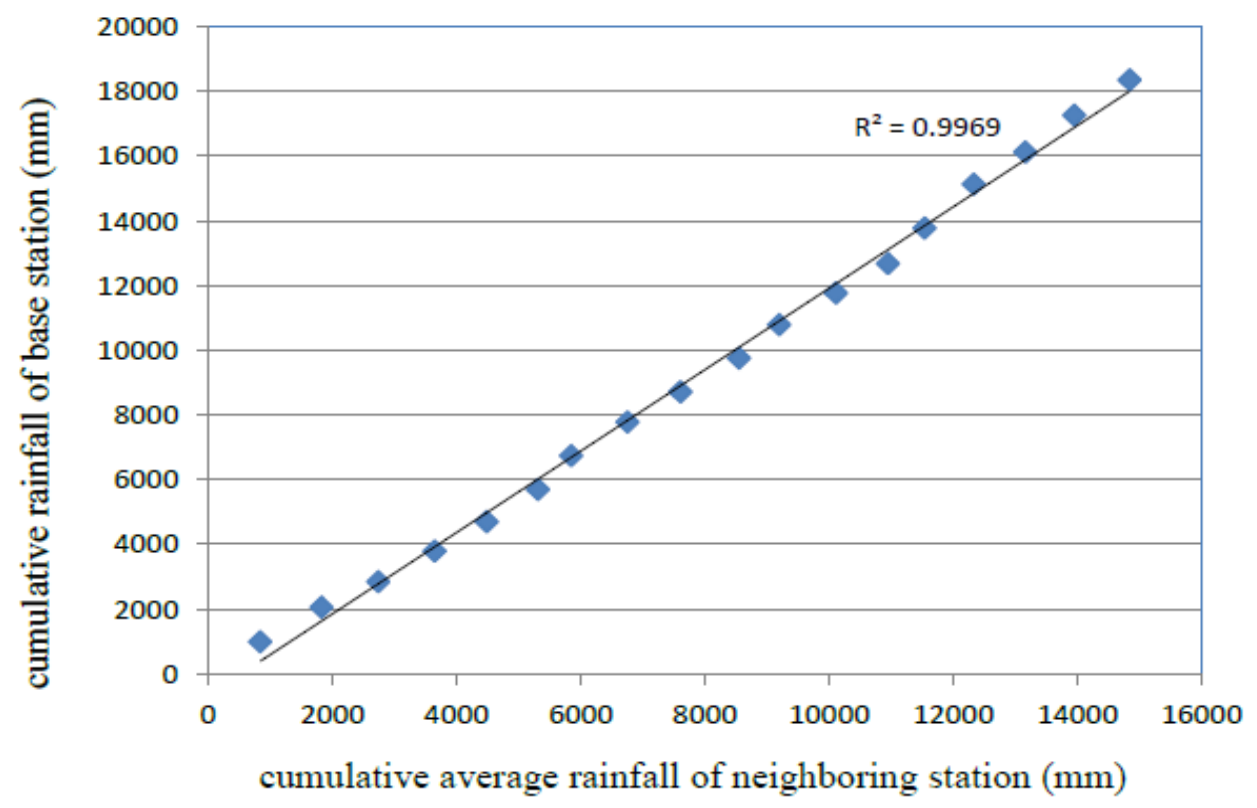

Figure 10. Double mass curve of Hirna Metrological station

According to the hypothesis test the result of homogeneity test for rainfall data shows that the collected data 
were homogeneous as homogeneity of the annual rainfall data from 1992 to 2015 shows. A sample test result for Hirna stations show the restriction of homogeneity assured that the observation is from the same population.

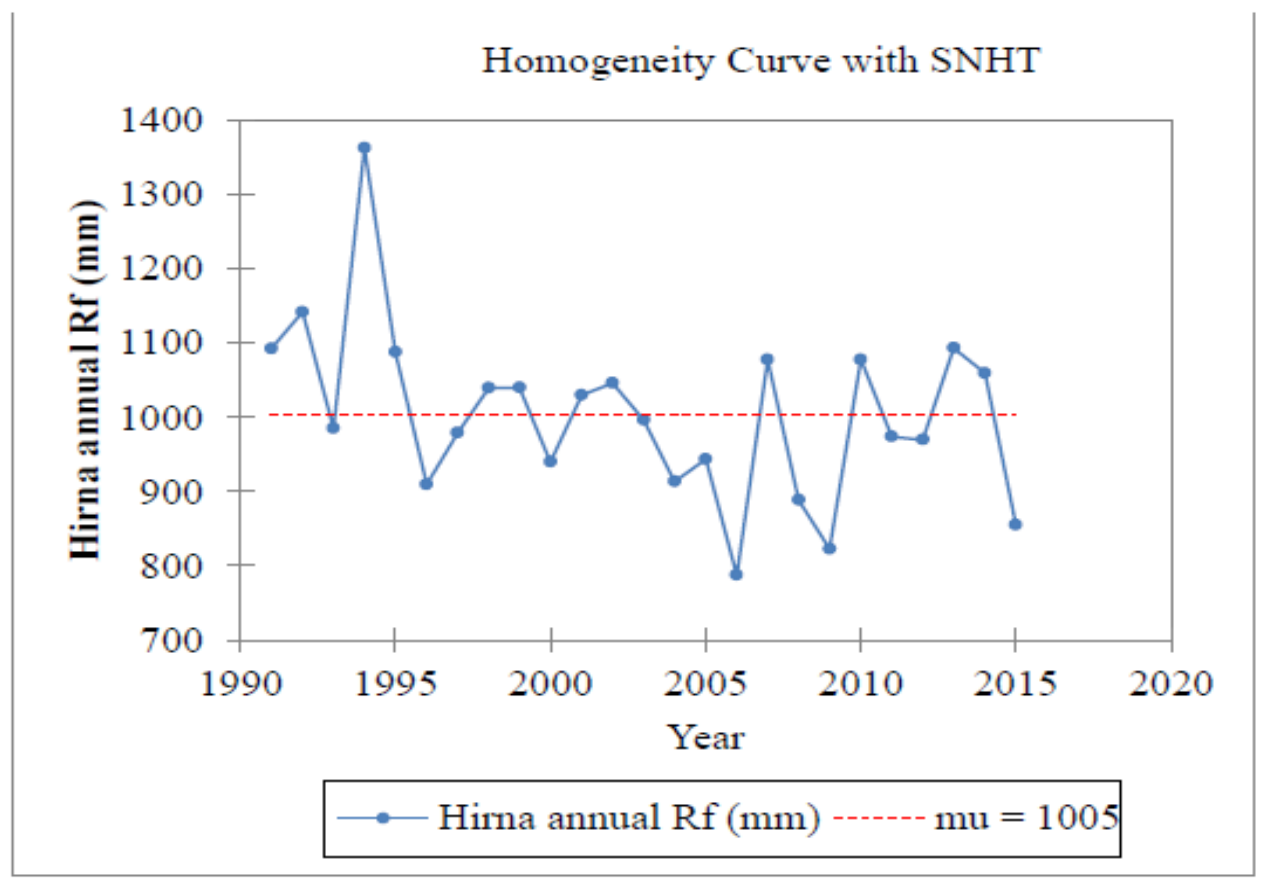

Figure 11. Homogeneity curve of annual rainfall at Hirna station section.

Both consistency and homogeneity of the remaining metrological station were written under Appendix

\subsubsection{Digital Elevation Model}

DEM of the study area created from contour map was digitized from the topographic maps of 1:60,000 scale with contour interval of $30 \mathrm{~m}$ as below Figure 13 .

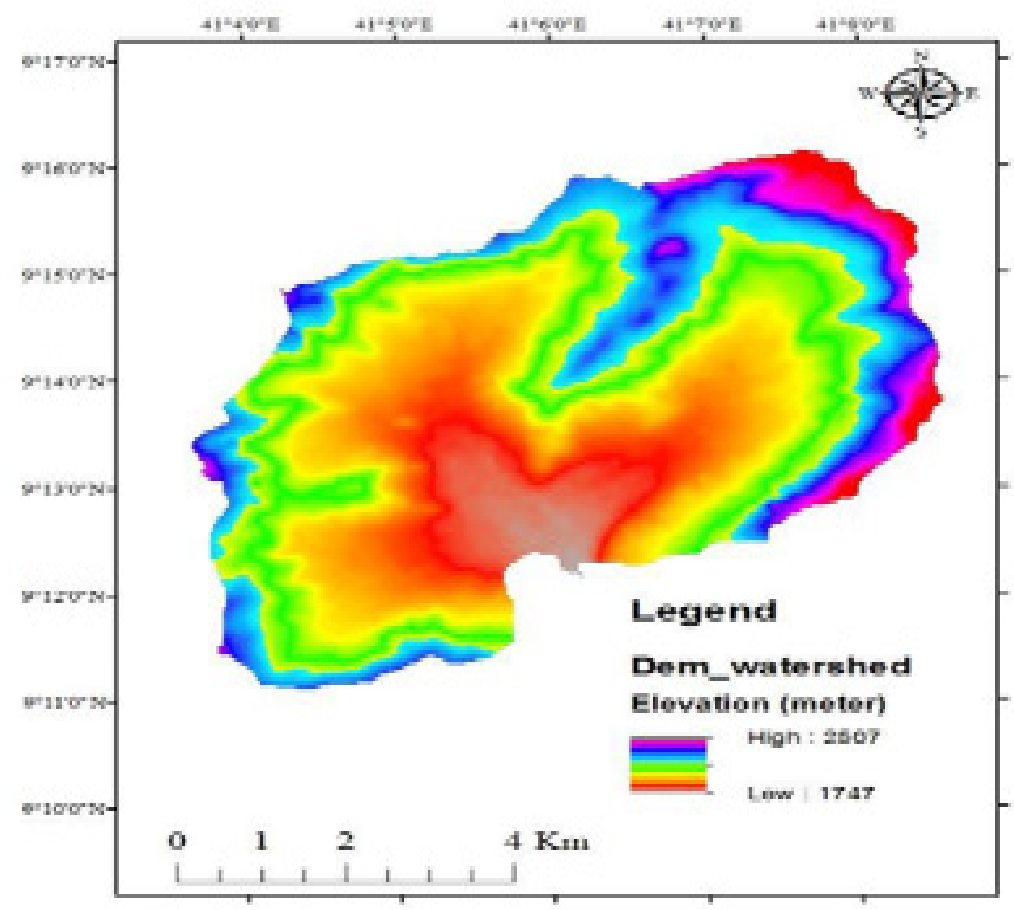

Figure 12. DEM of study watershed

\subsection{Soil Loss of the Watershed}

The model parameters (land use land coverage, soil loss management practices, rainfall erosivity, soil erodibility and land topography) were identified. 


\subsubsection{Land use and land cover factor $(C$ value factor $)$}

The attribute and spatial information on the present status of land use land cover is an important point to estimate soil loss, prioritize areas for soil conservation measures and minimizing further land degradation. The results of $\mathrm{C}$ _value indicated that the watershed characterized as four land use land cover classes; dominantly $75.10 \%$ is bare land while the remaining $24.9 \%$ is cultivated land, settlement and forest land (Table 6 and Figure 14). C- Factor values of the watershed were 0.02 to 0.6 .

\begin{tabular}{|c|c|c|c|c|}
\hline & & factor) & Area coverage (m2) & Percentage $(\%)$ \\
\hline 1 & Forest land & 0.02 & $3,063,908.00$ & 5.80 \\
\hline 2 & Cultivated land & 0.17 & $6,413,076.40$ & 12.14 \\
\hline 3 & Settlement & 0.40 & $3,676,689.60$ & 6.96 \\
\hline 4 & Bare land & 0.60 & $39,672,326.00$ & 75.10 \\
\hline & Total & & $52,825,779.00$ & 100.00 \\
\hline
\end{tabular}

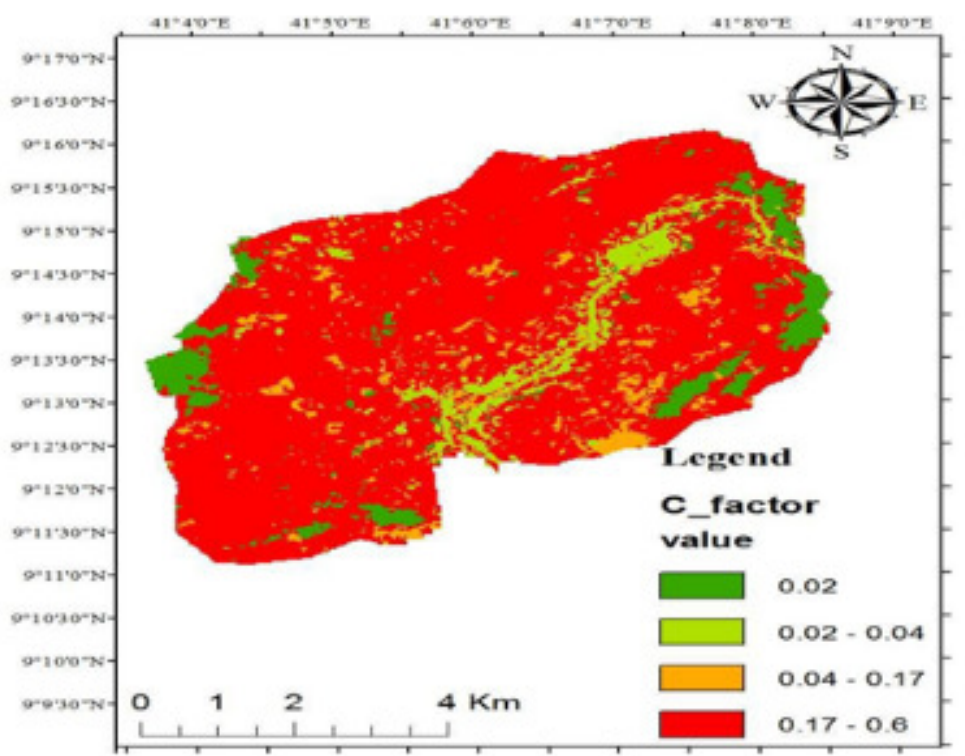

Figure 13. C_factor map of study watershed

\subsubsection{Erosion management practice factor ( $P-V a l u e)$}

The management practice factor, $\mathrm{P}$ value is one of the factors that govern the soil erosion rate which reflects the effects of practices that will reduce the amount and rate of the water runoff and thus reduce the amount of erosion. It depends on the type of conservation measures implemented and requires mapping of conserved areas for it to be quantified. In the study area, management and conservation practices did not get any attention, i.e. almost no management practices have done. So it is advisable to calculate $\mathrm{P}_{-}$factor of watershed as suggested by Shiferaw (2011).

Slope map, field information and land use/ land cover map were used to choose suitable P_factor of watershed, with this general information and procedure the $P_{-}$factor of watershed ranges from 0.58 to $1 . \overline{0}$ (Figure 15) 


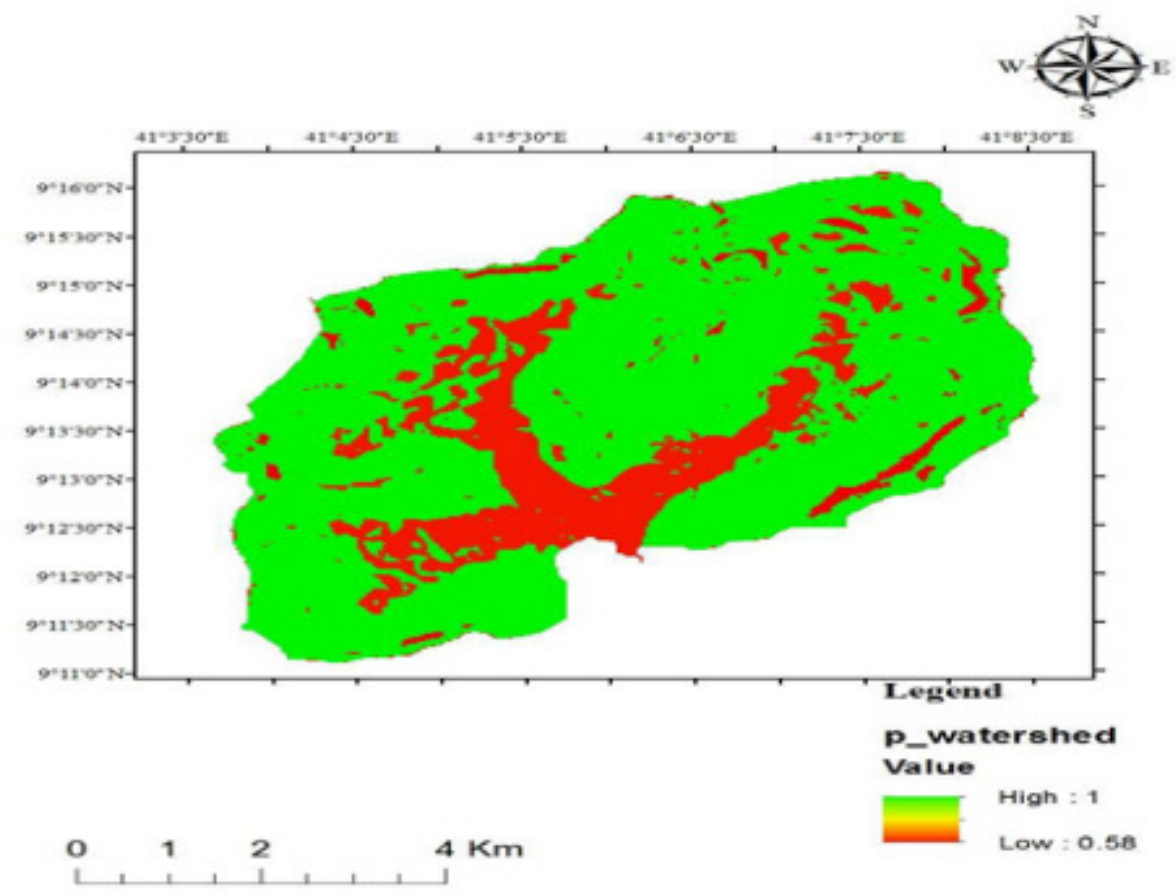

Figure 14. $P$ _factor of study watershed

3.3.3. Soil erodibility factor (K value)

The result indicated that soil erodibility value in the study watershed was 0.20 to 0.25 tons ha h ha $-1 \mathrm{MJ}-1 \mathrm{~mm}$ -1 (Table 9 and Figure 16).

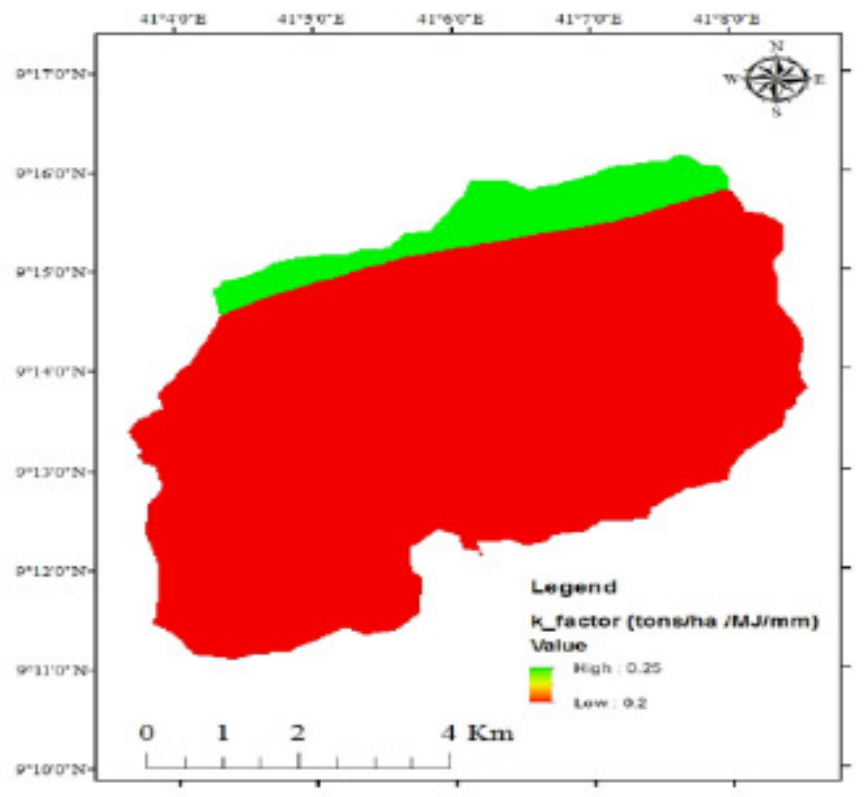

Figure 15. K_factor of study watershed 
Table 7. K_factor of study watershed

\begin{tabular}{|c|c|c|c|c|c|c|c|c|}
\hline 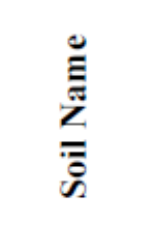 & 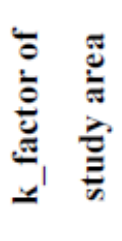 & 冚 & : & 莺 & $\stackrel{巳}{\mathrm{e}}$ & $\begin{array}{l}\frac{n}{\tilde{E}} \\
\frac{0}{0} \\
=\end{array}$ & 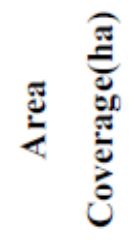 & 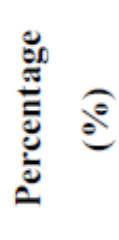 \\
\hline $\begin{array}{l}\text { Eutric } \\
\text { Leptosols }\end{array}$ & 0.20 & $\mathrm{BC}$ & 2 & & 2 & Sandy loam & 4805.05 & 90.96 \\
\hline Haplic & 0.25 & $\mathrm{BC}$ & 5 & & 5 & Sandy clay & 477.55 & 9.04 \\
\hline Luvisols & & & & & & loam & & \\
\hline
\end{tabular}

\subsubsection{Rainfall erosivity factor (R-value)}

Soil loss is closely related to rainfall partly through the detaching power of raindrops striking the soil surface and partly through the contribution of rain to runoff. The soil loss is closely related to rainfall partly through the detaching power of raindrop striking the soil surface and partly through the contribution of rain to runoff (Morgan, 2005). The representative mean annual rainfall of the watershed is ranging $756-1164.36 \mathrm{~mm}$.

Table 8. Metrological station with their erosivity (Rainfall erosivity)

\begin{tabular}{llllllll}
\hline Station & Name & Latitude & Longitude & Altitude & $\begin{array}{l}\text { mean } \\
\text { rainfall(mm) }\end{array}$ & $\begin{array}{l}\text { annual } \\
\text { erosivity } \\
\text { mmh1ha-1yr-1) }\end{array}$ & (MJ \\
\hline 1 & Hirna & 9.22 & 41.10 & $1720 \mathrm{~m}$ & 1001.00 & 554.44 \\
2 & Gelamso & 8.82 & 40.52 & $1860 \mathrm{~m}$ & 1164.36 & 646.25 \\
3 & Chiro & 9.08 & 40.87 & $1660 \mathrm{~m}$ & 924.12 & 511.24 \\
4 & Machara & 8.34 & 40.20 & $1820 \mathrm{~m}$ & 968.00 & 535.90 \\
5 & Chelanko & 9.40 & 41.57 & $1860 \mathrm{~m}$ & 756.00 & 416.80 \\
\hline
\end{tabular}

Using the above data and Kriging technique in ArcGIS 10.1 rainfall erosivity map of each neighboring metrological station and the study watershed rainfall erosivity map were developed (Figure 17).

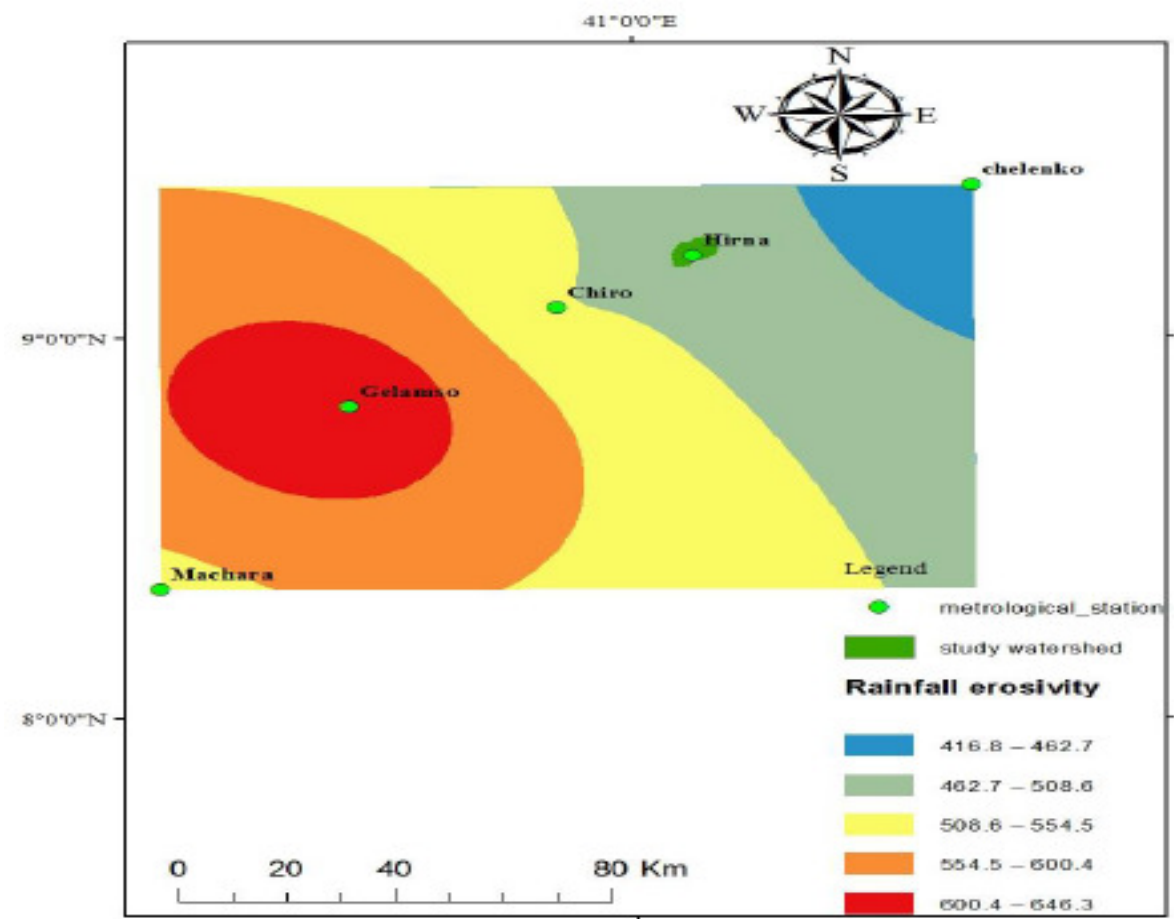

Figure 16. Rainfall erosive factor map of neighbor metrological station

The result showed that R-factor value in the watershed ranged between 549.20 to $556.40 \mathrm{MJ} \mathrm{mm} \mathrm{h}^{-1} \mathrm{ha}^{-1}$ year ${ }^{-1}$ with medium values occurring in the watershed (Figure 18). 


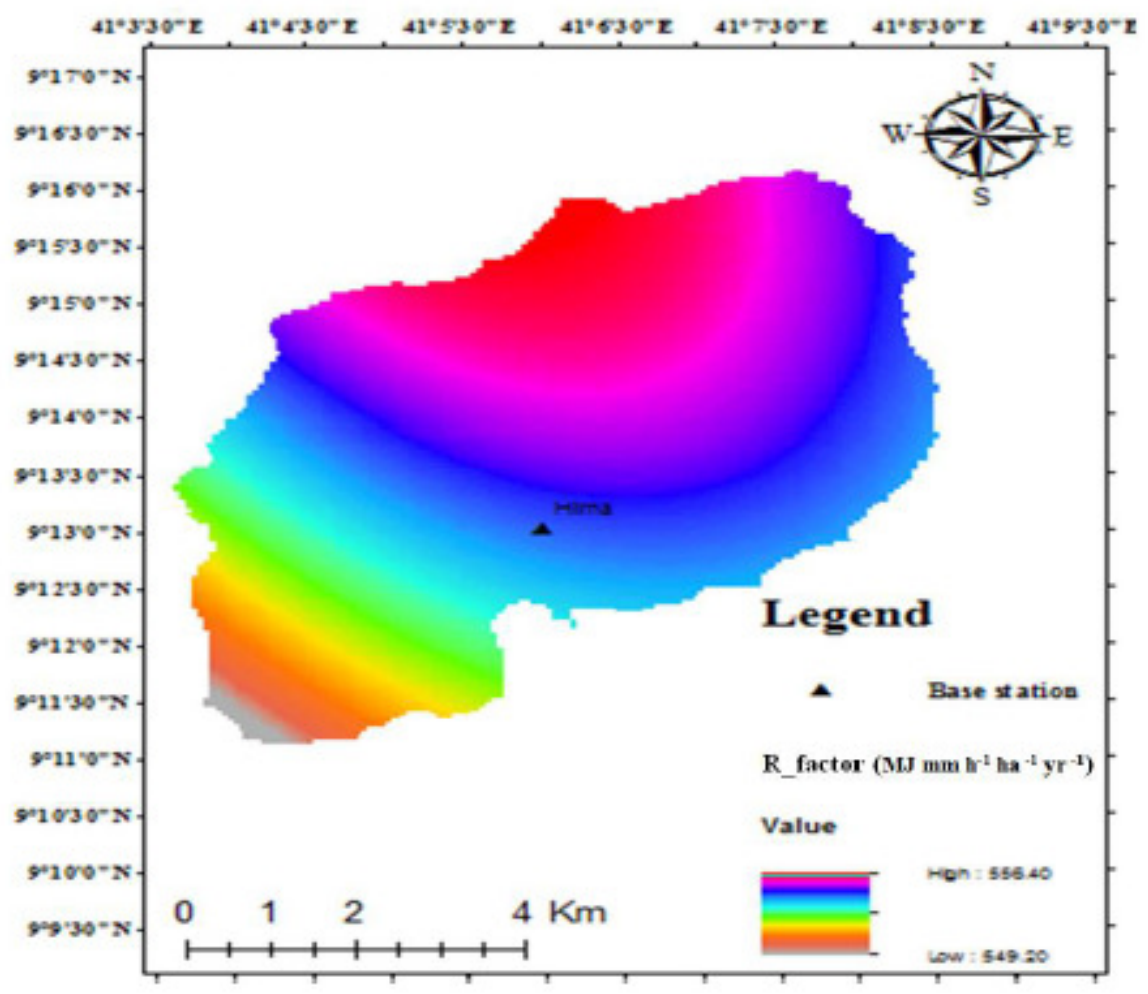

Figure 17. Rainfall erosivity factor of study watershed

\subsubsection{Slope length and slope steepness factor (LS factor)}

The local slope gradient (S_factor) influences flow velocity and the rate of erosion. Slope length (L_factor) describes the distance between the origin and termination of inter-rill processes. The steeper and longer the slope, the higher is the erosion. As slope length increases, total soil erosion and soil erosion per unit area increase due to the progressive accumulation of runoff in the down slope direction. The slope length factor and slope degree factors were typically combined together and the topographic factor map that was a function of both slope steepness and length of study watershed were developed (Figure 19).

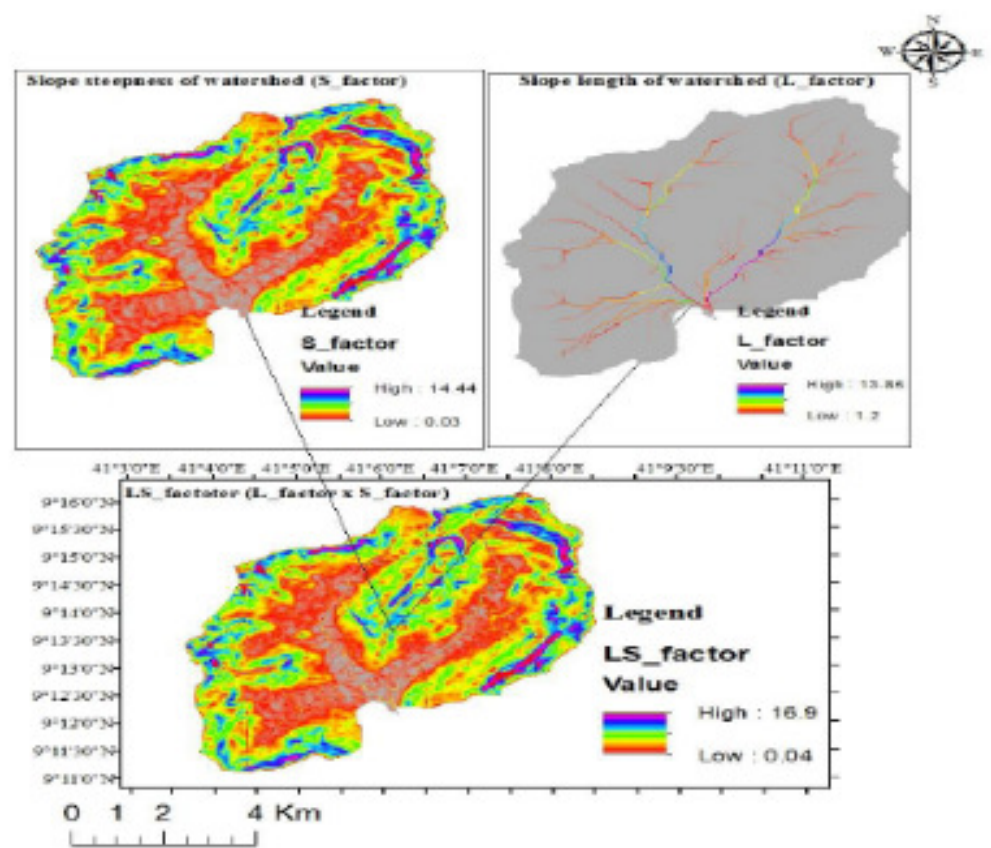

Figure 18. Slope length and steepness of study watershed

3.4. Soil Loss Estimation

The Revised Universal Soil Loss Equation (RUSLE) has been used widely all over the world including Ethiopia 
(Kaltenrieder, 2007) because of its simplicity and limited data requirement. The advent of geographical information system (GIS) technology has allowed the equation to be used in a spatially distributed manner because each cell in a raster image comes to represent a field-level unit. Even though the equation was originally meant for predicting soil erosion at the field scale, its use for large areas in a GIS platform has produced satisfactory results. By delineation of micro-watersheds as erosion prone areas according to the severity level of soil loss, priority is given for a targeted and cost-effective conservation planning (Kaltenrieder, 2007). As shown in Table 9 and Figure. 20 , Based on the analysis, the annual average soil loss of watershed was estimated as $26.61 \mathrm{ton} / \mathrm{ha} / \mathrm{yr}$ which is within the range of soil loss estimate for Ethiopian highlands by the soil conservation research project (SCRP) which ranges from 0 to 300 ton/ha/yr (Nyssen et al., 2004) and Bobe (2004) as estimated in East and west Hararghe zone districts, in the range of $1.74-135 \mathrm{t} / \mathrm{ha} / \mathrm{yr}$. The total annual soil loss potential from 5282.6ha watershed was $140,569.99$ tons year ${ }^{-1}$. About $36.60 \%$ (1,933.42 ha) of watershed was classified under high to very high soil loss class while the remaining $63.40 \%$ (3349.168 ha) of watershed categorized under slow to moderate soil loss class (Mati et al., 2000) (Table 9).

The normal SLT (soil loss tolerance) value for Ethiopia ranges from 2 to 16 tons ha ${ }^{-1} \mathrm{yr}^{-1}$ (Hurni et al., 2008). This denotes the maximum allowable soil loss that will sustain an economic (Wischmeier and Smith, 1978; FAO and UNEP, 1984 \& Gebreyesus and Kirubel, 2009) and a high level of productivity. In this study, the area with a soil loss potential higher than the SLT was 4875.6 ha (Table 9) that accounts $92.3 \%$ of total watershed coverage.

\begin{tabular}{lllll}
$\begin{array}{l}\text { Table 9. Soil loss classification and distribution for different intensity of erosion class } \\
\text { Soil loss rating }\end{array}$ & \multicolumn{4}{c}{$\begin{array}{c}\text { Area coverage } \\
\text { Hectare (ha) }\end{array}$} \\
Class & ton/ha/yr & Description & 316.96 & Percent (\%) \\
I & $0-5.0$ & None & 89.80 & 6.00 \\
II & $5.0-15.0$ & Slight & 2377.17 & 1.70 \\
III & $16-30$ & Moderate & 565.24 & 45.00 \\
IV & $31-50$ & Moderate & 158.48 & 10.70 \\
V & $51-200$ & High & 1774.95 & 3.00 \\
VI & $>200$ & very high & $\mathbf{5 2 8 2 . 6}$ & $\mathbf{1 0 0}$ \\
Total & & & $\mathbf{5 2 . 6 0}$
\end{tabular}

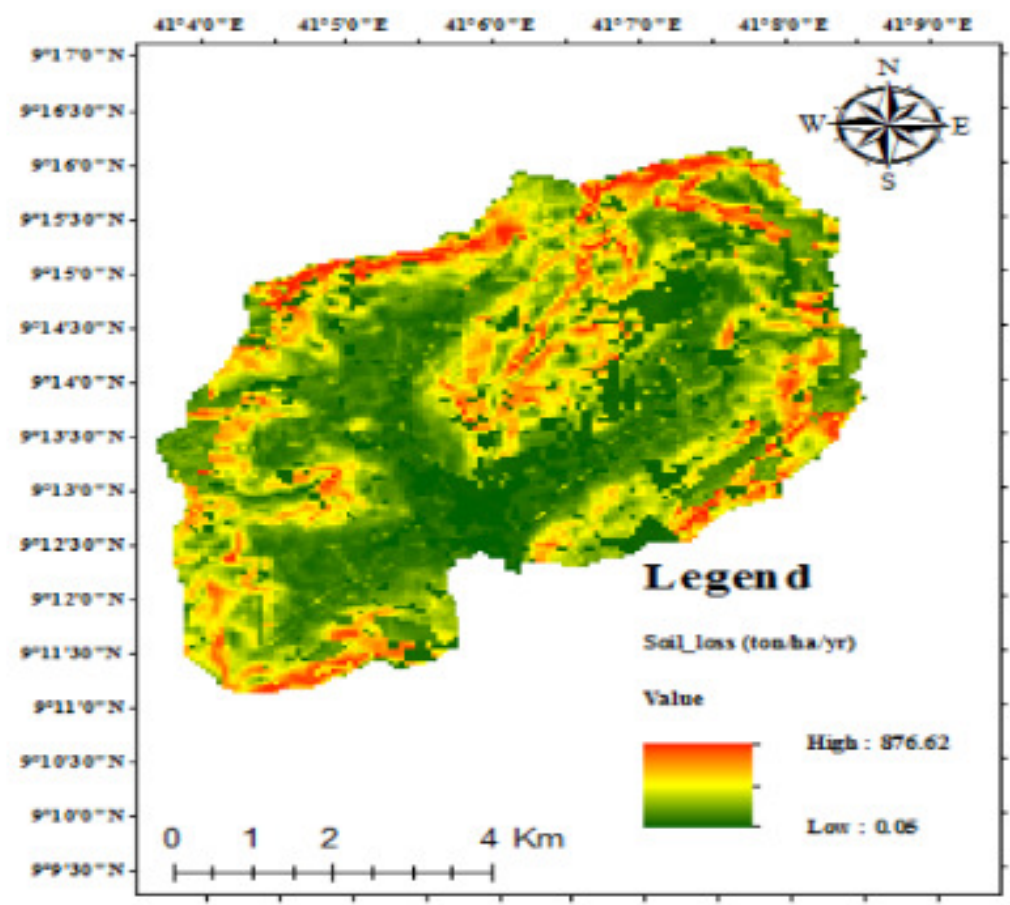

Figure 19. Soil loss map

\subsection{Sediment Yield}

Sediment yield is commonly estimated by the empirical formula under methodology section. Therefore at the outlet of watershed or at the construction of weir 25,311.802 tons of soils were deposited, which is about $18.01 \%$ of the total soil loss from the watershed. 


\subsection{Field Measurement of Watershed Soil Loss}

Beside spatial estimation of soil loss, ground truth measurement by sediment controlling point is so important to identify the real value of soil loss from watershed to take possible measurements. From the control point (sample area), the depth of 0.6 to $1.8 \mathrm{~cm}$ of soil were loosed within each $24 \mathrm{hrs}$ rainfall, which was $1,452.407$ to $4,753.332$ $\mathrm{cm}^{3}$ volume. From the sample area total annual soil loosed was estimated as $81,017.9032 \mathrm{~cm}^{3}$ from an area of 48 $\mathrm{m}^{2}$. Depending on this sample measurement the total annual soil loss from the study watershed of 5,282.60 ha, $89,163.7 \mathrm{~m}^{3}$ was loosed. This means about $16.88 \mathrm{~m}^{3} /$ ha soil loosed. The volume of soil loosed was changed to mass bases by multiplying the dry bulk density with the total volume of soil loosed.

The average dry bulk density of deposited soil from watershed is $1.321 \mathrm{~g} / \mathrm{cm}^{3}$, which is equivalent with 1,321 $\mathrm{kg} / \mathrm{m}^{3}$. From this value about $22,296.83 \mathrm{~kg}$ of soil loss per ha. These show $22.29683 \mathrm{ton} / \mathrm{ha} / \mathrm{yr}$ soil losses within each season, i.e. 117,801.98 tons/yr of soil were loss from the watershed.

\subsection{Comparison of soil loss with the help of RUSLE and direct field measurement with control point}

On the study area to compare and contrast, the result of soil loss with the help of Model and direct field measurement of soil loss with the help of runoff control point were done. The model follow the agents for soil loss like land use land coverage, soil loss management practices, rainfall erosivity, soil erodibility and slope length factor. This parameters run in ArcGIS 10.1, Map Algebra, Raster Calculator to identify the annual soil loss rate from the watershed. From the model an average of annual soil loss $26.61 \mathrm{ton} / \mathrm{ha} / \mathrm{yr}$ which total 140,569.99 ton/yr of soil loss from the watershed.

The results from experiment show an average of $22.30 \mathrm{ton} / \mathrm{ha} / \mathrm{yr}$ soil losses within each season, which a total of $117,801.98$ tons/yr of soil were loss from the watershed. These values were a beat difference; this is because of less rainfall at the season rather than the mean annual; annual rainfall used in the model.

\subsection{Assessment of Irrigation Project and Structural Problem}

Hirna small scale irrigation project structures were stated and evaluated during the study with the aspects of sediment deposition

\subsubsection{Canal bed load}

The canal bed load was estimated according to the technique listed under section 3.4.4 and by using equation 3.12. The total sediment deposited in the canal length of $1,025 \mathrm{~m}$, were estimated and about $88.42 \mathrm{~m}^{3}$ of sediment were deposited, which is about $116,802.56 \mathrm{~kg}$ (116.80 tons).

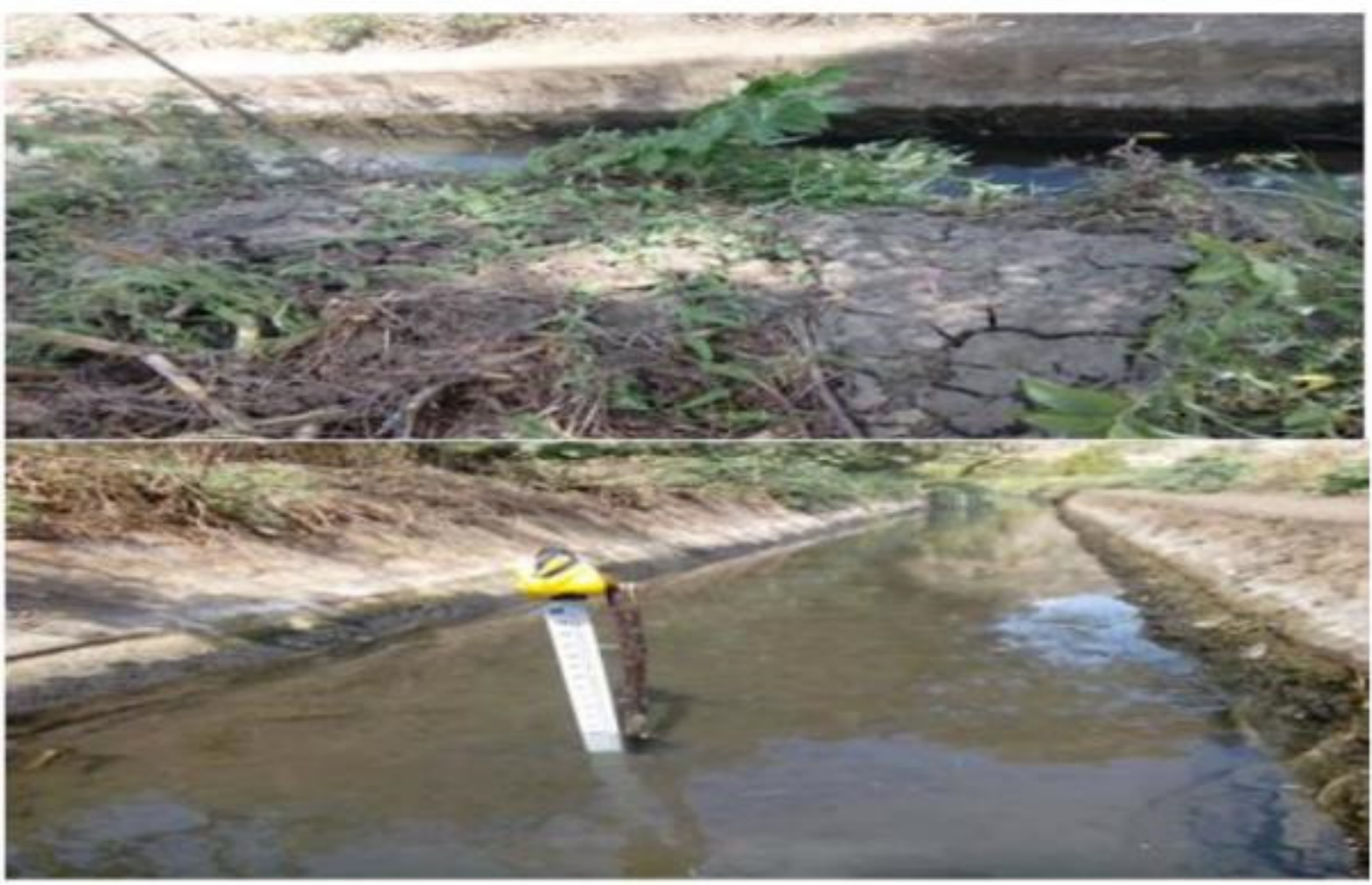

Figure 20. Sediment deposition in irrigation canal

\subsubsection{Sedimentation in canal systems}

In this section the effects of sediment on the discharge reduction of Hirna irrigation system were discussed. 
Deposition of bed material sediments has increased the canal bed slope as the system adjusted to increase its transporting capacity to match the sediment input. Sediment deposition resulted in a large reduction in the quantities of diverted water.

Sedimentation in the canal head increased and dramatically it reduced the quantity of water depth diverted into $41.67 \%$ to be available at the upper section of the canal, $27.6 \%$ at the middle and $17.4 \%$ at the lower (tail) of the canal, ought of the flow that could have been designed.

The second effect of sediment deposition is reducing the cross sectional areas below the design. As the canal slope is larger than design when the canal is silted, the flow velocities are also larger; therefore the reduction in cross sectional area does not result in a loss in proportional discharge capacity. This does not mean that canal sedimentation and the resultant increase in slopes is acceptable. Increasing the sediment transporting capacity of the canals implies higher concentrations of bed material sediments being transported to the fields, and eventually, problems of command at the field outlets.

\subsubsection{Main canal seepage}

The problem of main canal seepage is observed since there is the water loss underneath of soil at the scheme where the canal is unlined and damaged due to road pass over it. The seeping water is seen through the underneath of the soil and hence significant quantity of irrigation water is lost prior to arrive the distributing water courses. Besides the loss of valuable diverted water, the seepage moisture is also a problem in some part of the structure.

\subsubsection{Damage on intake gate and sluice gates}

Observation through the canal show there is highly damaged, broken intake gates and closed sluice gates with sediment. The figures possibly indicate how the schemes are performing under difficult condition. The cause for the problem of gates can be mainly attributed to improper scheme operation and sediment deposition.

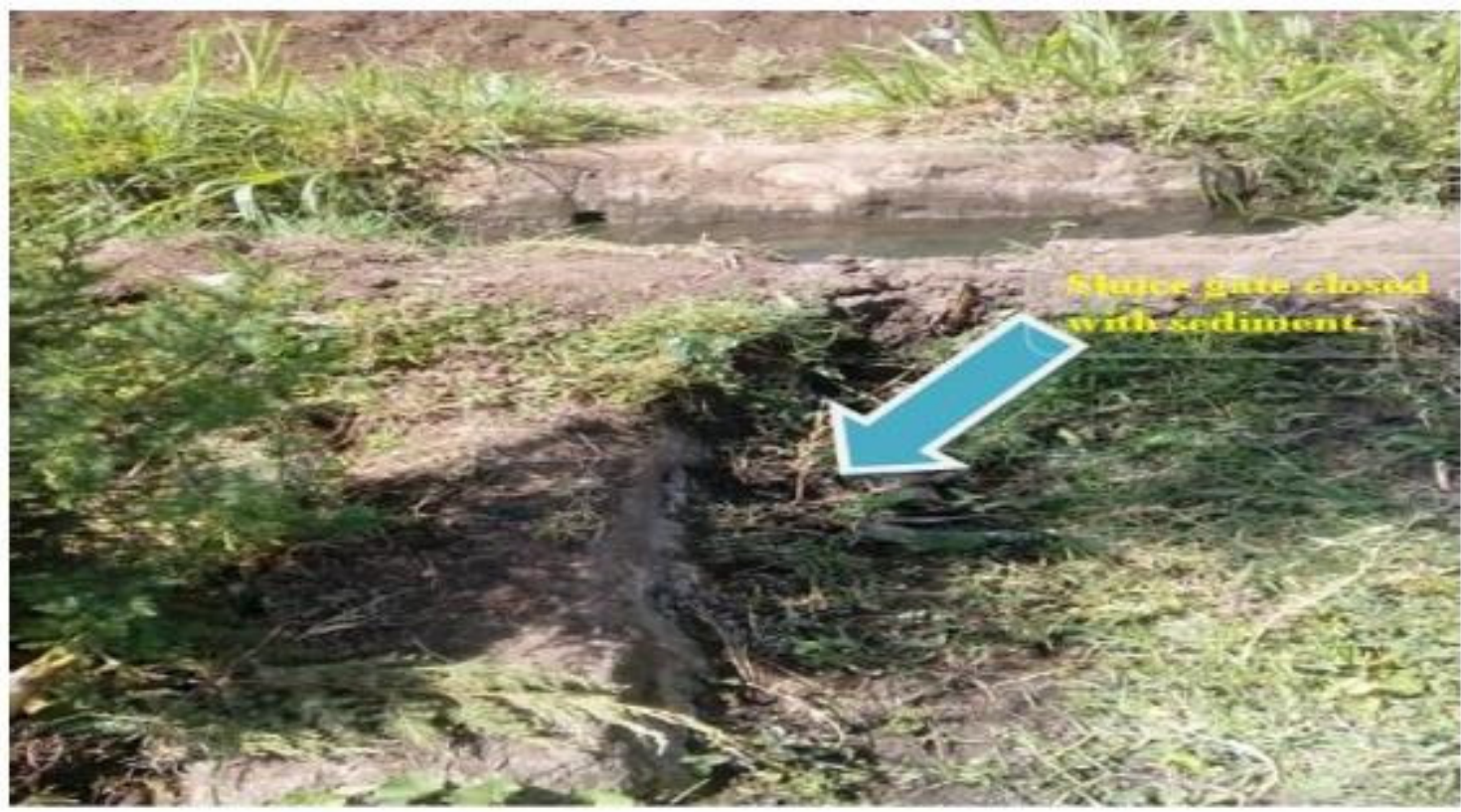

\subsubsection{Problem on (CD) cross drainage works}

Figure 21. Damaged gate and closed sluice gate

CD- works are structures carrying discharges of a natural stream across a canal intercepting the stream. When a canal is to be taken to the farm land, it crosses a number of natural streams at the distance between the headwork and command area. As observation done at project site proper design was not prepared for the passage of drainage stream and it was just not constructed based on experience and didn't lined separately from the canal. Hence serious scouring is observed.

\subsubsection{Road passage over the canal}

The roads pass the farmers and their livestock over the canal passage didn't constructed on some important place, this cause canal damage and deposition of soil/sliding in the canal. The following figure depicts the case: 

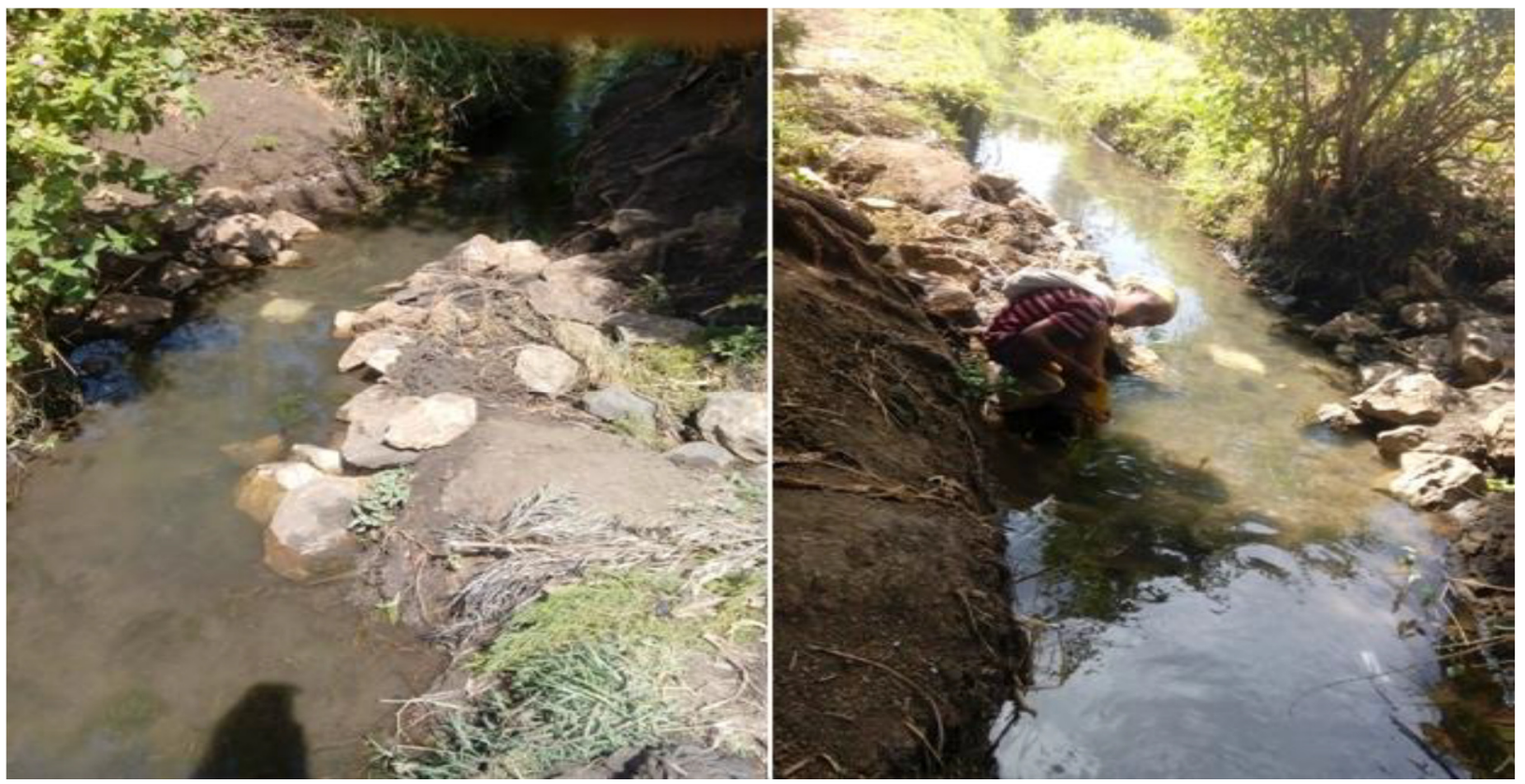

Figure 22. Canal problems on study project (DC_problems)

Design didn't address properly the need of foot path within the command area and crossing of canals causes the blocking of the canal purpose. This indicates proper provision of foot path through the canal. In the following figure the foot path across the main canal indicates the need of proper provision of foot path at this place but not also considered by the designer.
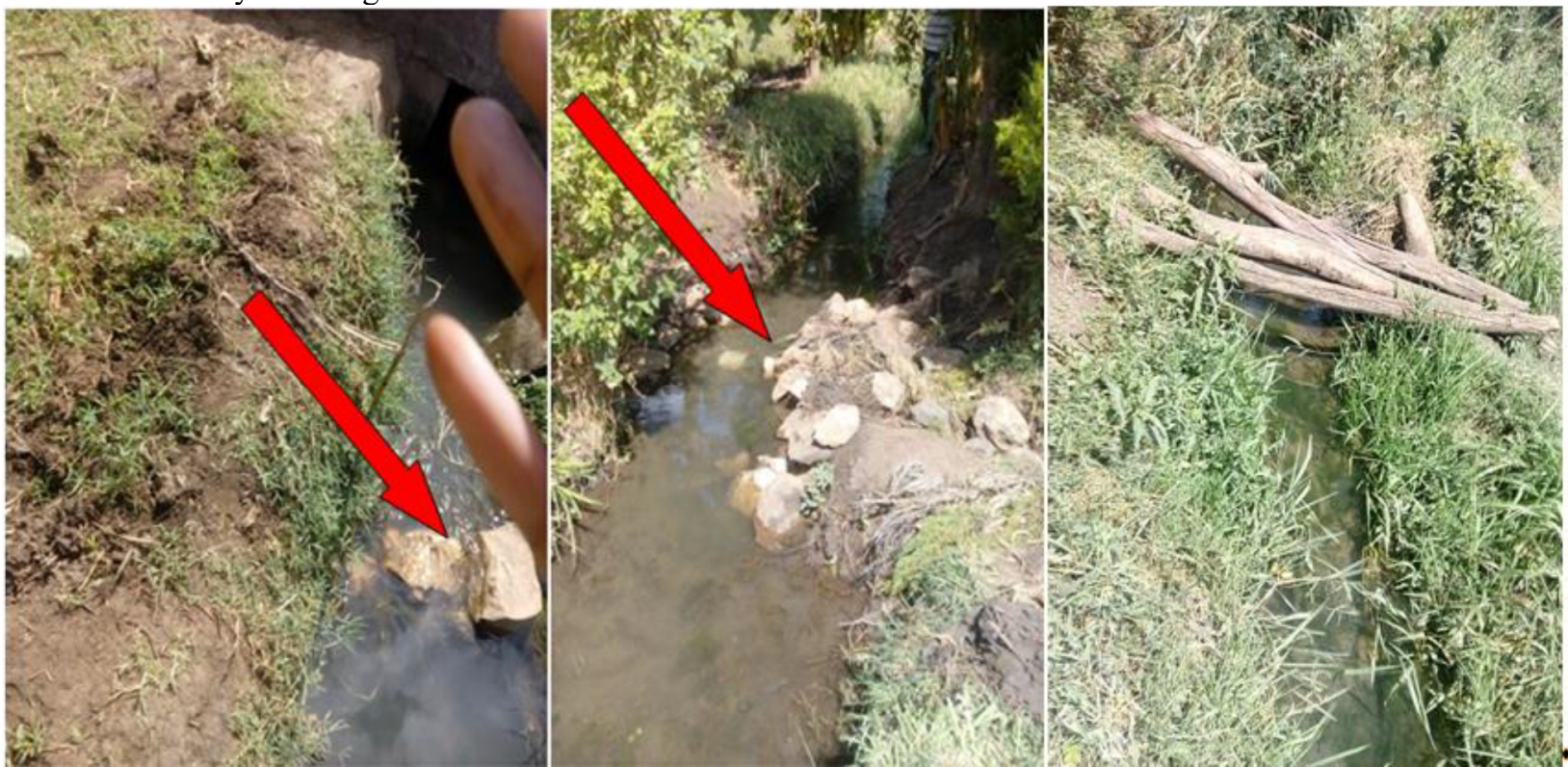

Figure 23. Cross road problem through the canal

An irrigation project didn't consider cattle troughs around the project and culverts for the pass of the cattle, this leads to the damage of the canals.

\subsubsection{Redesign of Hirna small scale irrigation in view of discharge and bed material transportation Lacey method of canal design}

Lacey (1930) in the early part of the $20^{\text {th }}$ century based on data from India, Pakistan, and Egypt and elsewhere supports. The Lindley Regime Concept, in which Lindley wrote: "When an artificial channel is used to convey silt water, both bed and banks scour or fill, changing depth, gradient and width, until a state of balance is attained at which the channel is said to be in regime". There are four relationships in the Lacey method; all four must be satisfied to achieve "regime" conditions. Depending on lacey's equation and by taking the designed discharge from design document of Hirna small scale irrigation 2010/2011 which is $0.02 \mathrm{~m}^{3} / \mathrm{s}$, the particle size deposited at the bed of the canal from survey data is coarse sand which it's diameter identified from general information of USBR data on permissible velocities for non-cohesive soils which $2.50 \mathrm{~mm}$. As the slope of canal bed increased the sediment transportation will be facilitated, so the designing way is to adjust and identify if the bed slope is 
enough to transport sediment deposited. The designed bed slope of the canal by using Lacey (1930) equation was $0.001 \mathrm{ft} / \mathrm{ft}$. From the design document of the structure the designed bed slope of the structure is 0.02 , which is 10 times less than what was designed by considering the particle diameter size of the structure. So from this result the first designed bed slope is less to remove the sediment deposited in the structure. Therefore this is also one of the factors for the sedimentation of irrigation canal.

Lacey with Manning general slope, velocity formula

The flow velocity designed with the help of Lacey versus Manning equation was $0.6 \mathrm{~m} / \mathrm{s}$. This velocity is the applicable velocity that is designed by considering the sediment deposited in the canal and it is applicable to remove sediments from the canal. With this equation the water velocity flow through the canal, is different from what was designed before (design document of Hirna small scale irrigation (2010/2011). But a recommended minimum permissible velocity if water carries silts is considered. The adequate velocity to prevent sedimentation $(\mathrm{V}=0.6$ to $0.9 \mathrm{~m} / \mathrm{s})$ is recommended, so the redesigned flow velocity were adequate to remove sediments through the canal.

\section{SUMMARY, CONCLUSIONS AND RECOMMENDATIONS \\ 4.1. Summary and Conclusions}

In Ethiopia billions of tons of soil are lost annually due to soil erosion, Because of greater population pressure and consequently more intensive cultivation; erosion losses have been increasing to an annual areal average of 7 ton/ha equivalent to depth $0.5 \mathrm{~mm}$ (Garzanti et al., 2006). Local erosion rates are highly spatially variable ranging from less than 1 to over 400 tons/ha/year (Hurni, 1988; Mitiku et al., 2006; Tebebu et al., 2010). In Ethiopia, soil erosion is a major challenge, posing a severe threat to the country's economy and development. The problem of sedimentation is clearly felt in the irrigation canals in dry years when there is scarcity of rain more silt-laden water is diverted to the canals.

Hirna small scale irrigation project watershed, west Hararghe is dominated by high soil erosion. In this watershed, much of the land is degraded and become bare land due to luck of soil conservation on the area. The general objective of this study is to estimate the watershed sediment loss, to evaluate the design concept of irrigation canals in view of water and sediment transport.

In order to understand the effect of soil loss and sediment formation in the project; the study has done on watershed. This approach, supported with RUSLE together with GIS provides great advantage to estimate soil loss rate over areas. The steps followed include data base establishment from primary and secondary data source using ArcGIS 10.1 software. In addition, data were collected through field sampling, field measurement, surveying equipment and structure observation. Based on RUSLE model analysis the total amount of soil loss in Hirna watershed was estimated to be 140,569.99 tons year-1 from 5,282.6 ha area with annual average soil loss of 26.61 ton/ha/yr. The annual soil loss of the study area lay in the documented range of soil loss of Ethiopian highland (Hurni et al., 2008). The soil loss of each parcel in the watersheds was found in the range of 0.05 to $876.62 \mathrm{tha}^{-}$ ${ }^{1} \mathrm{yr}^{-1}$.

RUSLE has given the prediction on watershed soil loss and sediment deposition. Its results needed to compare with the actual field condition. Therefore, this will give some ideas for program improvement and applicability on the study area in the future. The two technique used in study show as the watershed highly affected by soil erosion and serious land degradation. As the result show around $75.5 \%$ of the watershed is degraded and become bare land.

Improper land use practice, unpracticed land management's were derived to form high soil erosion and land degradation which is the reason for high sediment deposition in irrigation structure. As a result shows the water discharge of irrigation canal were reduced and some hydraulic structure were damaged. The same as, as the redesigning comparison document show the designed flow velocity in the canal and the bed slope is not applicable to remove the sediment and bed materials. This reasons for sediment deposited of about 116.81 tons per season in the canal, which reduce the depth of diverted water with $58.33 \%$.

From the result, it can be concluded that if there is no regular maintenance in terms of sediment removal, there will be bed level rise of +20 to $+30 \mathrm{~cm}$ annual. This will affect the main canal ability to convey the water to meet the secondary canal and crop water requirement.

\subsection{Recommendations}

Based on the findings of this study, the following recommendations were made in order to address the damaged hydraulic structure by the soil loss from watershed.

$>$ The rate of soil loss in the watershed is high and action should be taken to reduce the soil loss in the watershed. The soil and water conservation measures (vegetative practice) and reforestation of bare land are needed.

$>$ Irrigation scheme design doesn't consider the farmers willingness; poor design and highly reduce of irrigated farm land. In other cases, deep canal incision makes operation and maintenance more difficult for the farmer. 
$>$ Other design challenges which make the operation and maintenance difficult is sedimentation problem in canals and this should be minimized by designing sand excluders which opens proportionally to the level of water in the river. The other method to prevent sediment problem is provision of sediment ejector or silt excluder will also recommended.

$>$ Development without beneficiariese ${ }^{\text {ee }}$ participation is like a house without foundation, so the designing of small scale irrigation project should have seen different aspects of the beneficiaries ${ }^{\text {ee }}$ social and economic aspects.

$>$ Further study should be conducted on the area to identify the impact of sediment deposition on command area and productivity of agricultural land.

\section{Acknowledgment}

Above all we would thank the Almighty and Merciful God for giving us strength, health, peace and encouragement in all our life. We thank Haramaya University for sponsoring this research and financial support through the study period, Ethiopian metrological agency for giving us metrological data and West Hararghe Water, Irrigation and Energy office for their welcoming and kindly support. We greatly wish to thank Mr. Alemayo for his contribution during Primary and secondary data collection, his help also goes until the final of this work with the contributions of different computer material, software, books and valuable ideas, guidance, and appreciation still the end. Additionally Mr. Shimelis Berhanu (PhD candidate), Ato Wendimu Shimelis(farmer), Efrem Mitiku and Yeharerwork for their constant and unlimited help and encouragement.

\section{REFERENCES}

Ackers, P. 1993. Sediment transport in open channels: Ackers and White update. Technical note No. 619, Proc. Institute. Civil engineering. Water, Mineral. \& Energy, United Kingdom.

Alexandersson, H. 1986. A homogeneity test applied to precipitation data. Journal of Climatology, 6, 661-675. Allison P.D. 2001. Rainfall missing data estimation (No. 136).

Arora, K.R. 1996. Irrigation Water Power and Water Resources Engineering. Standard Publishers and DiSTRIBUTORS, Delhi.

Ayalew Gizachew, 2014. A Geographic Information System Based Soil Loss and Sediment Estimation in Gerdi Watershed, Highlands of Ethiopia, Journal of Environment and Earth Science 4(19), 62-75.

Ayalew Gizachew, 2015. A Geographic information system based soil loss and sediment estimation in Zingin watershed for conservation planning, highlands of Ethiopia, Journal of Environment and Earth Science 3(1), 28-35.

Bayramin, I., O Dengiz., O Baskan, M Parlak. (2003). Soil Erosion Risk Assessment with ICONA Model; Case Study: Beypazari Area. Turk Journal of Agriculture and Forestry 27(2003).

Bewket, W. and Teferi, E. 2009. Assessment of soil erosion hazard and prioritization for treatment at the watershed level: case study in the Chemoga watershed, Blue Nile basin, Ethiopia. Land degradation and development.

Bobe, B. Woreka, 2004. Evaluation of soil erosion in the Hararghe region of Ethiopia using soil loss models, rainfall simulation and field trials (doctoral dissertation) university of Pretoria, South Africa.

CSA. 2008. Ethiopian Population and Housing Census results, CSA, Ethiopia.

Dahmen, 1994. Role of sediment transport in operation and maintenance of supply and demand based irrigation canals. MachaiMaira Branch canals.

Desbiez, A., R. Matthews., B.Tripathi and Ellis-Johnes, J. 2004. Perceptions and Assessment of Soil Fertility by Farmers in the Mid-hills of Nepal: Journal of Agriculture, Ecosystems and Environment 103: pp 191-206.

Desmet, P.J.J. and G. Govers, 1996. A GIS procedure for automatically calculating the USLE LS factor on topographically complex landscape units. Journal of Soil \& Water Conservation 51: 427-433

Ethiopian Agricultural Research Organization (EARO), 2000. A participatory agro-ecology based problem identification survey of SH2-1, West Wollega, Ethiopia. Bako Agricultural Research Centre, Bako, Ethiopia. $28 \mathrm{pp}$.

FAO (Food and Agricultural Organization), 2007. Crop prospects and food situations. Report No. 3, Food and Agriculture Organization of UN, Rome.

FAO and UNEP, 1984. Provisional Methodology for Assessment and Mapping of Desertification. FAO, Rome, Italy.

FAO, 2002. Restoring the land. http://www.fao.org/inpho/vlibrary/u8480e/u8480E0d.htm.

Fleitmann, D., Dunbar, R.B., McCulloch, M., Mudelsee, M., Vuille, M., McClanahan, T.R., Cole, J. E. and Eggins, S. 2007. East African soil erosion recorded in a 300 year old coral colony from Kenya, Geophys. Res. Lett., 34, L04401, doi:10.1029/2006GL028525

Food and Agriculture Organization of the United Nations (FAO), 2008. Global Review of Good Agriculture Extension and Advisory Service Practice. FAO, Rome, Italy. 138pp.

Garzanti, E., Ando S., Vezzoli, G., Ali Abdel., Megid, A. and El, Kammar, A. 2006. Petrology of Nile River sands 
(Ethiopia and Sudan): Sediment budgets and erosion patterns. Earth and Planetary Science Letters, 252 (3-4), pp. $327-341$.

Gebreyesus, Brhane and Kirubel Mekoen, 2009. Estimating Soil Loss Using Universal Soil Loss Equation (USLE) for Soil Conservation Planning at Medego Watershed, Northern Ethiopia. Journal of American Science 2009: 5(1), 58-69. Marsland Press.

Herman, D., Krishna, P., Paudel and Nestor, M. 2015. Sediment transport in irrigation canals: - a new approach / Herman Depeweg, UNESCO-IHE, Delft, Netherlands, pp (1)

Holden, 2006. Soil Erosion and Smallholders' Conservation Decisions in the Highlands of Ethiopia. World Development Vol. 27, No. 4, pp. $739-752$.

Hurni, H. 1985. Erosion-Productivity-Conservation Systems in Ethiopia. Proceedings 4th International Conference on Soil Conservation, Maracay, Venezuela, pp: 654-674.

Hurni, H. 1988. Degradation and conservation of the resources in the Ethiopian Highlands, International journal of soil and water conservation Mt. Res. Dev., 8, 123-130

Lacey, G. 1930. Stable Channels in Alluvium Paper 4736, Proc. of Institution of Civil Engineers, Vol. 229, William Clowes \& Sons Ltd., London, U.K. P. 259-292.

Lim, K.J., Sagong, M., Engel, B.a., Tang, Z., Choi, J. and Kim, K. 2005. GIS-based sediment assessment tool. Catena, 64(1), 61-80. http://doi.org/10.1016/j.catena.2005.06.013

Mati, B.M., R.P.C. Morgan, F.N., Gichuki J.N., Quinton, T.R., Brewer and H.P. Liniger, 2000. Assessment of erosion hazard with the USLE and GIS: A case study of the Upper Ewaso $\mathrm{Ng}^{\text {ee }}$ iro North basin of Kenya. Internl. Journal. Appl. Earth Obsrv. and Geo-inform.

Ministry of Agriculture and Rural Development (MoARD) and World Bank, 2007. Thematic Papers on Land Degradation in Ethiopia: MoARD and World bank Publication, June, 2007.

Mitiku Habtamu., Herweg, K. and Stillhardt, B. 2006: Land Resource Management and Environmental Protection Department, Mekelle University, Mekelle, Ethiopia, Center for Development and Environment (CDE), University of Bern and Swiss National Center of Competence in Research (NCCR)North-South, Bern, Switzerland, 269 pp.,

MOANRMD (Ministry of Agricultural Natural Resource Management Directorate), 2011. Small scale irrigation situation analysis and capacity needs assessment. A tripartite cooperation between Germany, Israel and Ethiopia, octeber 2011, Addis Ababa, Ethiopia.

Moard and world bank, 2007. Africa Development Indicators, the International Bank for Reconstruction and Development/World Bank, Washington, DC, 2007.

Morgan, R.P. (2005). Soil Erosion and Conservation. Silsoe College, Cranfield University

Nyssen, J., Poesen, J., Moeyersons, J., Haile, M., Deckers, J. and Lang, A. 2004. Human impacts on the environment in the Ethiopian and Eritrean Highlands states of the art, Earth Science. Reviews, 64, 270-320.

Pereira, L., Gilley, and Jensen, M. 1996.Research Agenda on Sustainability of Irrigated Agriculture. Journal of Irrigation and Drainage Engineering, 122(3): 172-177.

Pimentel. D. 1998. Land use, erosion and water resources. In: Biswas A.K. (ed), journal of Water resources, environmental planning, management, and development. Tata McGraw- Hill Publishing Limited, New Delhi, India. pp. 37-71.

Ranga Raju K.G. 2001. Sedimentation of river, Reservoir and canals. Journal of irrigation and drainage engineering, ASCE. 126 (3), pp.300-312. Presents an analysis of data from small to large size Indian catchments, and proposes an equation for sediment yield.

Ranga Raju K.G., Garde R.J. and Bhardwaj R.C. 1981. Total load transportation in alluvial channels, Journal of hydraulic engineering, ASCE. 108(2), PP.179-191. (A review of the state of art of sedimentation transport theory at the time).

Renard K, Foster GR, Wessies GA, Porter JP.1994. Revised Universal Soil Loss Equation (RUSLE). Journal of Soil and Water Conservation 46:30-33.

Schultz, B., Thatte, C. D. and Labhsetwar, V. K. 2005. Irrigation and drainage: Main contributors to global food productivity. Journal of Irrigation and Drainage, 54: 263- 278.

Shiferaw, A. 2011. Estimating Soil Loss Rates for Soil Conservation Planning in the Borena Woreda of South Wollo Highlands, Ethiopia. Journal of Sustainable Development in Africa, 13(3): 87-106

Tamene, L.2005.Reservoir siltation in the drylands of northern Ethiopia: causes, source areas and management options. PhD Thesis, Ecology and Development Series 30, Center for Development Research, University of Bonn. 84-138.

Tebebu Tigist., Abiy, A.Z., Zegeye Assefa., Dahlke, H.E., Easton, Z.M., Tilahun, Seuifu. A., Collick, A.S., Kidnau, S., Moges, S., Dadgari, F. and Steenhuis, T.S. 2010. Surface and subsurface flow effect on permanent gully formation and upland erosion near Lake Tana in the northern highlands of Ethiopia, Hydro. Earth Syst. Sci., 14, 2207-2217, doi: 10.5194/hess-14-2207-2010,

Tukur, a.I., Olofin, E.a. and Mashi, S.a. (2013). Rate of sediment yield in the conveyance canals of Kano River 
Irrigation Project (Phase I) north-western Nigeria. Journal of Environment and Earth Science, 3 (12), 155162. http://www.cabdirect.org/abstracts/20143087947.html?resultNumber=0\&q=title:(irrigation project)

Unep (United Nation environmental protection), 2000. Provisional Methodology for Assessment and Mapping of Desertification. FAO, Rome, Italy.

Van Rijn, L. C. 1984, Sediment transport, part I: bed load transport. Journal of. Hydraulic Eng. (ASCE), 110(10), 1431-1456.

Vemu, S., and Pinnamaneni, U. B. (2012). Sediment yield estimation and prioritization of watershed using Remote Sensing and GIS,(September), 529-533.

Wischmeier,W.H and D.D.Smith, 1978.Predicting Rainfall Erosion Losses-A Guide to Conservation. Agricultural Handbook 537. US Department of Agriculture: Washington,DC.

Yang, C.T. 1981.Unit stream power equation for total load. Journal of Hydrology 40pp 123·138.

\section{Biography of the Author}

First Author (Hailu Mosisa Chala):- was born in Daawoo Woreda, south west Shoa zone on February 1991. He attended his elementary school at Daawoo Kunche, secondary school at Busa and Junior Secondary School at Hibret firee Senior Secondary School. After he completed his secondary high school education he joined Wollega University and graduated with BSc Degree in Water Resource and Irrigation management in July 2012. After graduation he was employed by Haramaya University Chiro Campus, where he served as Graduate assistant and assistant lecturer under Water Resource and Irrigation Engineering department from November 2012 until he joined Haramaya University Institute of Technology in October 2014 to study his Master of Science degree in Irrigation Engineering. On November 17, 2016 he has graduated with MSc Degree from Haramaya Institute of Technology and started serving at Oda Bultum University as a lecturer, Researcher and Water Resources \& Irrigation Engineering department head.

\section{APPENDICES}

\subsection{Appendix Tables}

Appendix Table 1. Soil loss collected from gauged point.

Sample area coverage $8 \mathrm{~m} * 6 \mathrm{~m}=48 \mathrm{~m} 2$

Diameter of barrel $=58 \mathrm{~cm}$

Lasher $1 \mathrm{~m}$, with $30 \mathrm{~cm}$ height, $40 \mathrm{~cm}$ width, and $10 \mathrm{~cm}$ lower width enter to barrel.

\begin{tabular}{|c|c|c|c|}
\hline $\begin{array}{l}\text { Sediment taken within } \\
24 \mathrm{hr}\end{array}$ & $\begin{array}{l}\text { sediment collected in } \\
\text { depth }(\mathrm{cm})\end{array}$ & radius squire $(\mathrm{cm} 2)$ & Volume (Ir2h) (cm3) \\
\hline $\mathrm{Jul} / 05 / 2015$ & 1.15 & 841 & 3036.851 \\
\hline $\mathrm{Jul} / 08 / 2015$ & 1.1 & 841 & 2904.814 \\
\hline Jul/10/2015 & 1.5 & 841 & 3961.11 \\
\hline $\mathrm{Jul} / 13 / 2015$ & 1.8 & 841 & 4753.332 \\
\hline Jul/15/2015 & 1.3 & 841 & 3432.962 \\
\hline Jul/18/2015 & 1.6 & 841 & 4225.184 \\
\hline $\mathrm{Jul} / 22 / 2015$ & 1.2 & 841 & 3168.888 \\
\hline Aug/03/2015 & 1.4 & 841 & 3697.036 \\
\hline Aug/05/2015 & 1.2 & 841 & 3168.888 \\
\hline Aug/07/2015 & 1.4 & 841 & 3697.036 \\
\hline Aug/08/2015 & 1.5 & 841 & 3961.11 \\
\hline Aug/10/2015 & 1.1 & 841 & 2904.814 \\
\hline Aug/16/2015 & 1.3 & 841 & 3432.962 \\
\hline Aug/20/2015 & 1.53 & 841 & 4040.3322 \\
\hline Aug/25/2015 & 1.2 & 841 & 3168.888 \\
\hline Aug/26/2015 & 1.3 & 841 & 3432.962 \\
\hline Aug/28/2015 & 1.5 & 841 & 3961.11 \\
\hline Aug/29/2015 & 1.5 & 841 & 3961.11 \\
\hline $\mathrm{Sep} / 05 / 2015$ & 1.3 & 841 & 3432.962 \\
\hline Sep/08/2015 & 1.1 & 841 & 2904.814 \\
\hline Sep/10/2015 & 0.75 & 841 & 1980.555 \\
\hline $\mathrm{Sep} / 12 / 2015$ & 0.6 & 841 & 1584.444 \\
\hline $\mathrm{Sep} / 15 / 2015$ & 0.55 & 841 & 1452.407 \\
\hline $\mathrm{Sep} / 16 / 2015$ & 0.8 & 841 & 2112.592 \\
\hline $\mathrm{Sep} / 21 / 2015$ & 1 & 841 & 2640.74 \\
\hline \multicolumn{2}{|l|}{ Total (annual soil loss) } & & 81017.9032 \\
\hline
\end{tabular}


Appendix Table 2. Guidelines for soil description

1. Potential soil erosion classes

\section{Soil Erosion Class}

Tonnes/hectare/yr

Very low (i.e. $<6$

tolerable)

Low 6-11

Moderate 11-22

High 22-33

Severe $>33$

Soil depth classes

o Very shallow ------ $<25 \mathrm{~cm}$

o Shallow ---------- 25- $50 \mathrm{~cm}$

o Moderately deep--- 50- $100 \mathrm{~cm}$

o Deep -------------- 100- $50 \mathrm{~cm}$

o Very deep ---------- > $150 \mathrm{~cm}$

3. Slope gradient classes (\%)

0.2 --------- Flat

$0.2-0.5$---------- level

$0.5-1.0------------N e a r l y ~ l e v e l$

1.0-2.0------------ Very gentle

2-5----------- Gently (gently undulating)

5-10------------ slopping (moderate)

10-15------------ strongly slopping

15-30------------ Moderately steep

30-60------------- Steep

$>60$-------------- very steep

Appendix Table 3. Soil profile description

Laboratory result of soil texture class of watershed

$\begin{array}{ll}\text { Sample code } & \text { Texture (\%) } \\ \text { Sand }(\%) & \text { Clay }(\%)\end{array}$

Us lu $2 \mathrm{a}-54-16$

$\begin{array}{lll}\text { Us lu 7a } & 58 & 22\end{array}$

Us lu 4c $\quad 62 \quad 18$

Us lu 3b $\quad 50$

Us lu 6b 62

$\%$ silt and very \% sand

fine sand

24.8

57.2

3.76

Appendix Table 4. Permeability information

\section{Texture class}

Clay, Silty clay

Silty clay loam, Sandy 5

clay

Sandy Clay loam, Clay 4

loam

Loam, Siltyloam,Silty 3

Loamy sand, Sandy 2

loam

Sandy
Sandy Loam

\section{Permeability}

Class

(

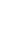

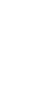

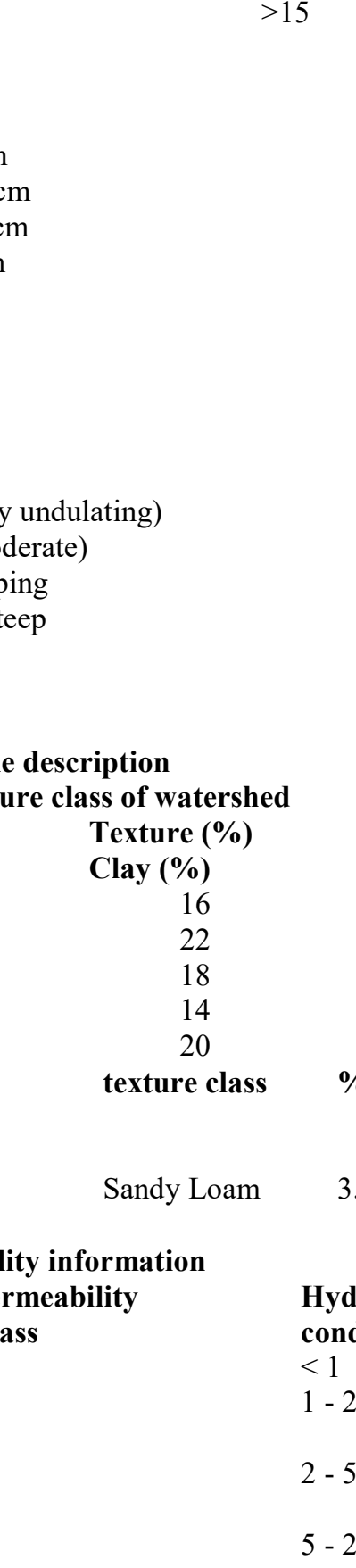




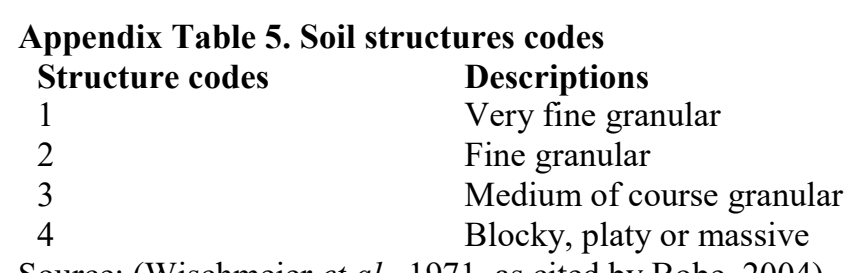

Source: (Wischmeier et al., 1971, as cited by Bobe, 2004)

Appendix Table 6. Mean annual rainfall of Hirna station for twenty four (1992 - 2015) years

\begin{tabular}{|l|l|l|l|l|l|l|l|l|}
\hline Year & $\mathbf{1 9 9 2}$ & $\mathbf{1 9 9 3}$ & $\mathbf{1 9 9 4}$ & $\mathbf{1 9 9 5}$ & $\mathbf{1 9 9 6}$ & $\mathbf{1 9 9 7}$ & $\mathbf{1 9 9 8}$ & $\mathbf{1 9 9 9}$ \\
\hline Annual Rf (mm) & 1142.1 & 985.2 & 1363.2 & 1080 & 909.6 & 979 & 1039.7 & 1040 \\
\hline Year & $\mathbf{2 0 0 0}$ & $\mathbf{2 0 0 1}$ & $\mathbf{2 0 0 2}$ & $\mathbf{2 0 0 3}$ & $\mathbf{2 0 0 4}$ & $\mathbf{2 0 0 5}$ & $\mathbf{2 0 0 6}$ & $\mathbf{2 0 0 7}$ \\
\hline Annual Rf (mm) & 940 & 1030.3 & 1046.3 & 996.6 & 913.5 & 943.835 & 787.3 & 1078 \\
\hline Year & $\mathbf{2 0 0 8}$ & $\mathbf{2 0 0 9}$ & $\mathbf{2 0 1 0}$ & $\mathbf{2 0 1 1}$ & $\mathbf{2 0 1 2}$ & $\mathbf{2 0 1 3}$ & $\mathbf{2 0 1 4}$ & $\mathbf{2 0 1 5}$ \\
\hline Annual Rf (mm) & 888.6 & 822.7 & 1078 & 974 & 970 & 1093.5 & 1059.6 & 855 \\
\hline
\end{tabular}

Appendix Table 7. Canal bed load identification sampling

Canal measurement and important information on study area

Top width $=110 \mathrm{~cm}$

Canal width at Water level $=80 \mathrm{~cm}$

Canal width at Sediment level $=60 \mathrm{~cm}$

Height of canal $=80 \mathrm{~cm}$

Cross-sectional slope $(\mathrm{m})=0.473=0.5$

Bottom width $=37 \mathrm{~cm}$

\begin{tabular}{|l|l|l|l|l|l|l|l|l|l|l|l|l|l|l|l|l|l|l|}
\hline $\begin{array}{l}\text { Distance } \\
(\mathrm{m})\end{array}$ & Upper \\
\hline
\end{tabular}


Appendix Table 8. Maximum permissible velocities recommended by Fortier and Scobey

\begin{tabular}{|l|l|l|}
\hline Material & \multicolumn{2}{|l|}{ Velocity (fps) } \\
\hline Clear water & Water with colloidal silt \\
\hline Fine sand, colloidal & 1.50 & 2.50 \\
\hline Sandy loam, non-colloidal & 1.75 & 2.50 \\
\hline Silt loam, non-colloidal & 2.00 & 3.00 \\
\hline Alluvial silt, non-colloidal & 2.00 & 3.50 \\
\hline Firm loam soil & 2.50 & 3.50 \\
\hline Volcanic ash & 2.50 & 3.50 \\
\hline Stiff clay, highly colloidal & 3.75 & 5.00 \\
\hline Alluvial silt, colloidal & 3.75 & 5.00 \\
\hline Shales and hard "pans" & 6.00 & 6.00 \\
\hline Fine gravel & 2.50 & 5.00 \\
\hline Coarse gravel & 4.00 & 6.00 \\
\hline Cobble and shingle & 5.00 & 5.50 \\
\hline
\end{tabular}

$\begin{array}{lll}\begin{array}{l}\text { Appendix Table 9. USBR data on permissible velocities for non-cohesive soils } \\ \text { Material }\end{array} & \begin{array}{l}\text { Particle diameter }(\mathbf{m m}) \\ \text { Mean velocity (fps) }\end{array} & 0.49 \\ \text { Silt } & 0.005-0.05 & 0.66 \\ \text { Fine sand } & 0.05-0.25 & 0.98 \\ \text { Medium sand } & 0.25 & \mathbf{1 . 8 0} \\ \text { Coarse sand } & \mathbf{1 . 0 0 - 2 . 5 0} & 2.13 \\ \text { Fine gravel } & 2.50-5.00 & 2.62 \\ \text { Medium gravel } & 5.00 & 3.28 \\ \text { Coarse gravel } & 10.00-15.00 & 3.94 \\ \text { Fine pebbles } & 15.00-20.00 & 4.59 \\ \text { Medium pebbles } & 25.00 & 5.91 \\ \text { Coarse pebbles } & 40.00-75.00 & 7.87-12.80 \\ \text { Large pebbles } & 75.00-200.00 & \end{array}$

Appendix Table 10. Manning roughness coefficient depending on construction material and depth ranges.

Lining category

Depth ranges

$0-15 \mathrm{~cm}$

Rigid

Grouted riprap

Stone masonry

Unlined

Asphalt

Bare soil

Rock cut

temporary

Jute net

Fiber glass roving

Straw with net

Cured wood mat

Gravel Riprap

$5 \mathrm{~cm}(\mathrm{~d} 50)$

$30 \mathrm{~cm}$ (d50)

Rock Riprap

$30 \mathrm{~cm}$ (d50)
Lining type

$$
15-60 \mathrm{~cm}
$$

0.015

\subsection{0}

0.042

Soil cement

0.025

0.018

0.023

0.045

Woven paper net

0.016

0.028

0.028

0.065

0.066

Synthetic

cm (d50)

$$
\begin{aligned}
& 0.044 \\
& 0.066
\end{aligned}
$$

mat2.5 0.036

$15 \mathrm{~cm}(\mathrm{~d} 50)$

- n-value different depth ranges

$>60 \mathrm{~cm}$

0.013

0.013

0.030

0.032

0.022

0.028

0.030

0.016

0.020

0.032

0.021

0.033

0.035

0.016

0.020

0.025

0.015

0.019

0.019

0.025

0.028

0.025

0.021

0.033

0.041

0.030

0.034

0.069

0.035

0.078

0.04 
7.2. Appendix Figure

Appendix Figure 1. Sediment control point/ Field sampling of sediment measurement

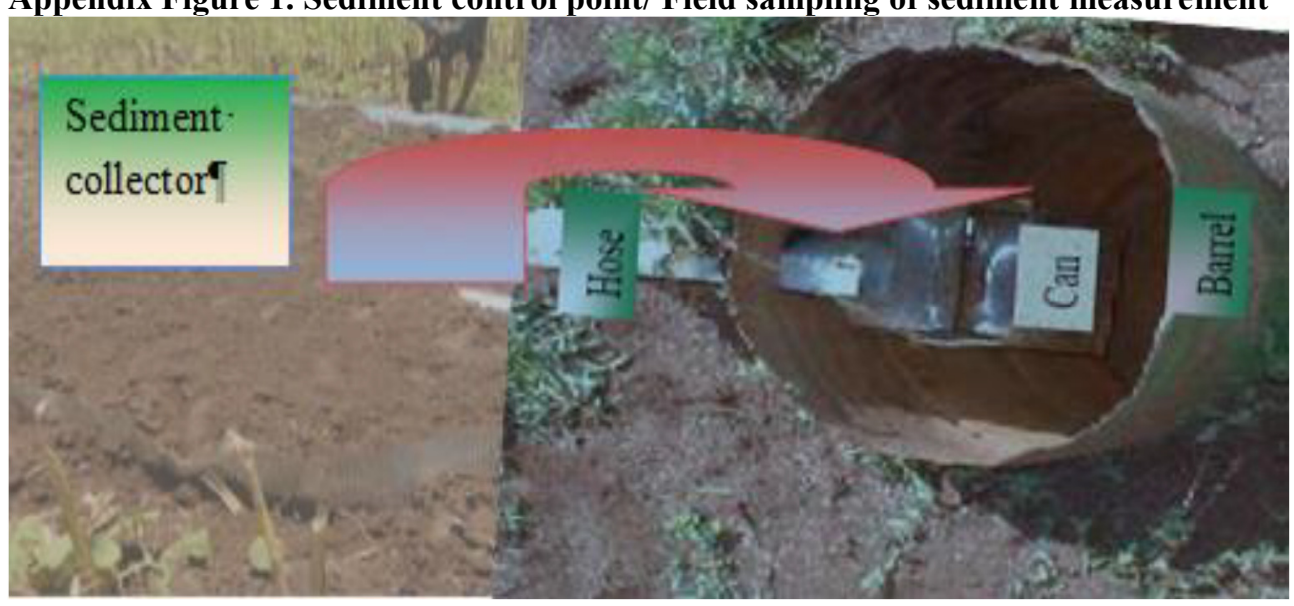

Appendix Figure 2. Field soil sample taking materials

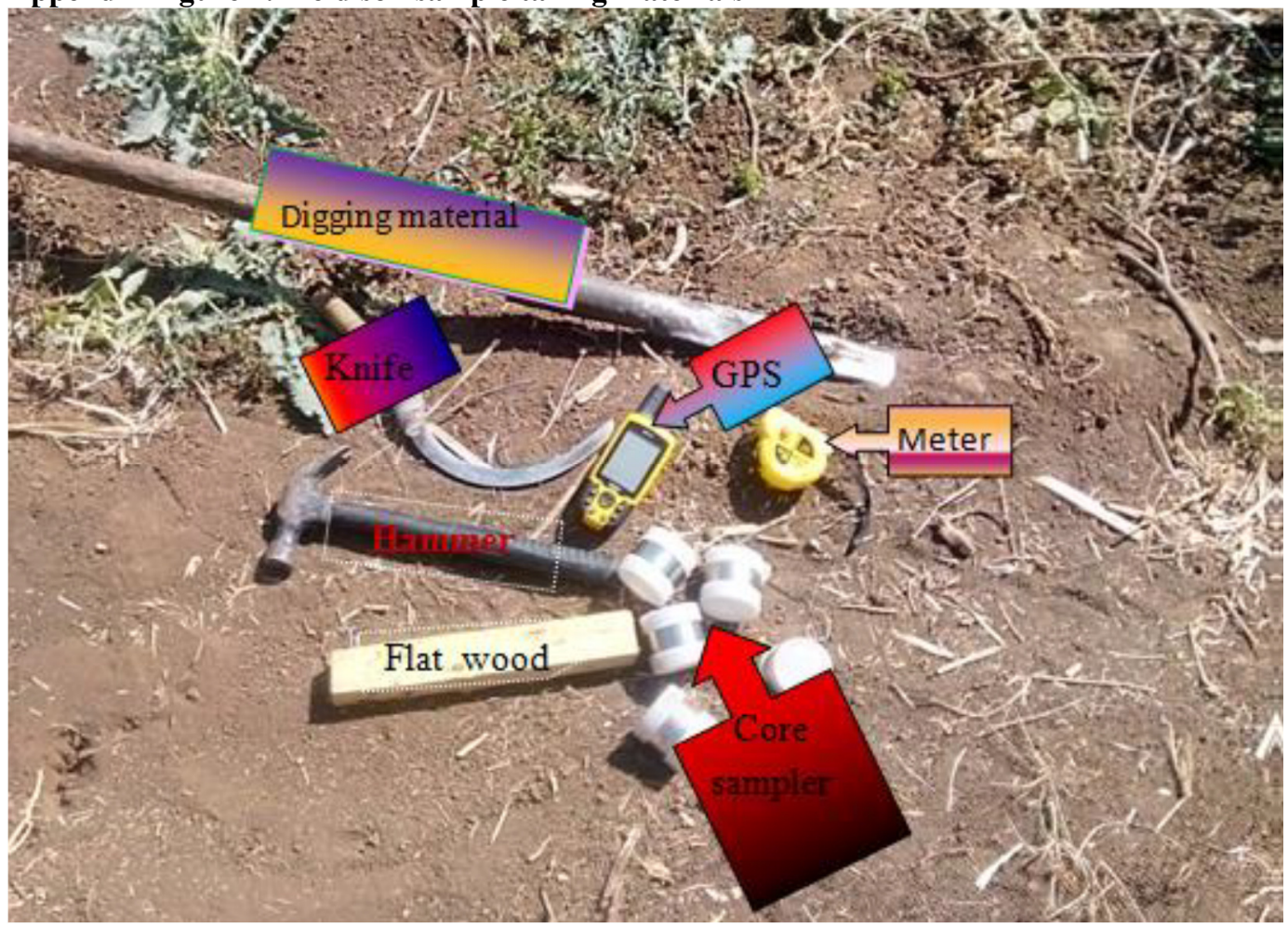




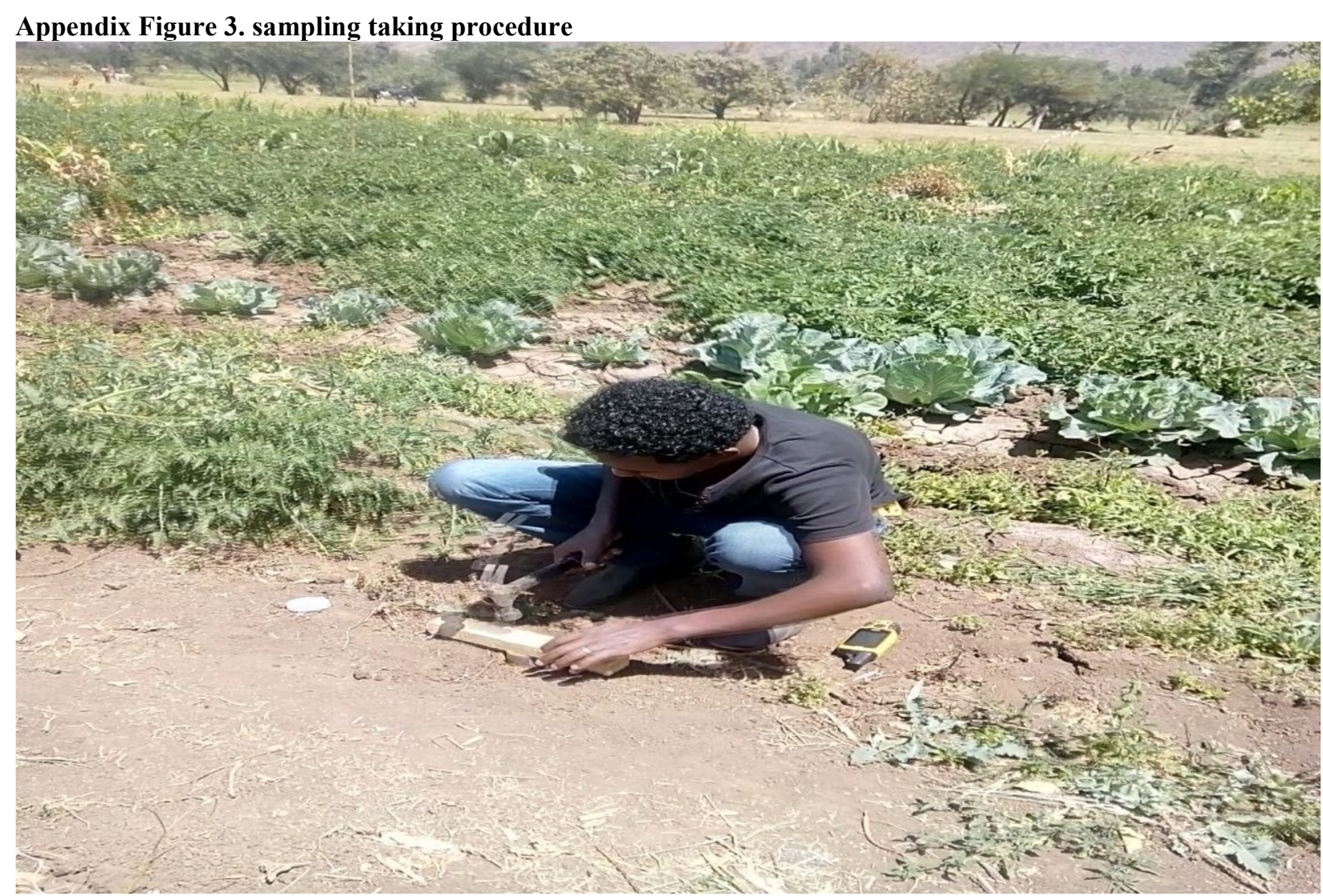

\section{Appendix Figure 4. Real field information taking with}

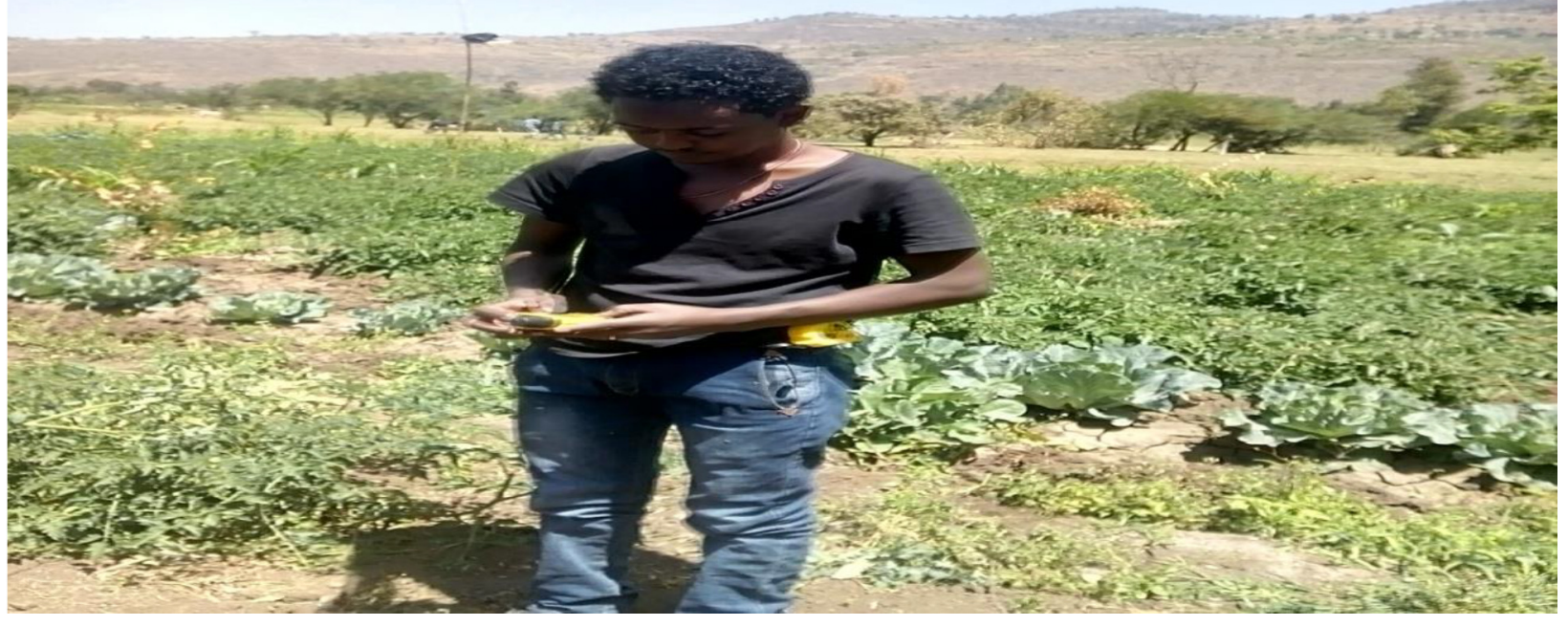



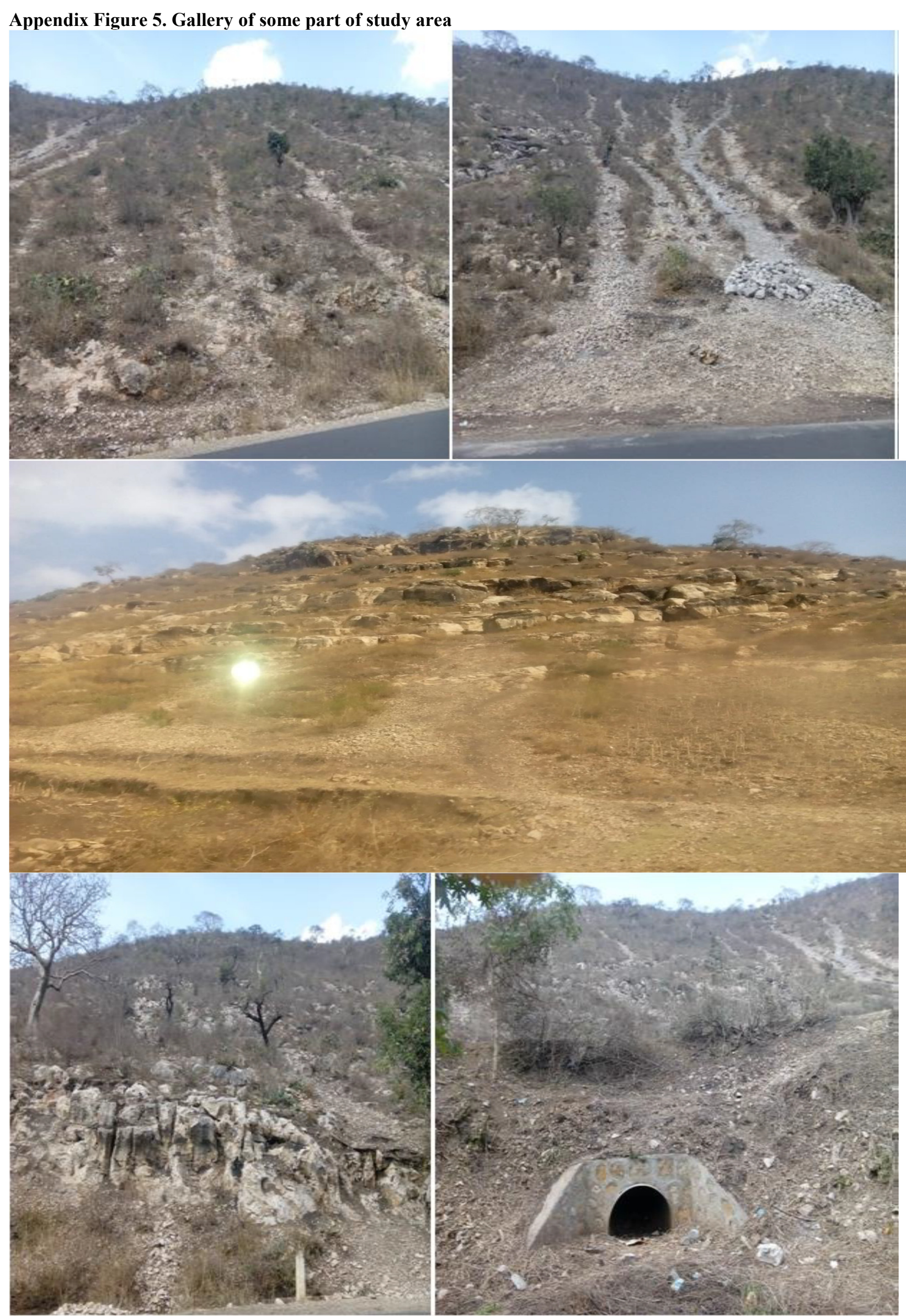


\section{Appendix Figure 6. Procedure of soil texture identification}

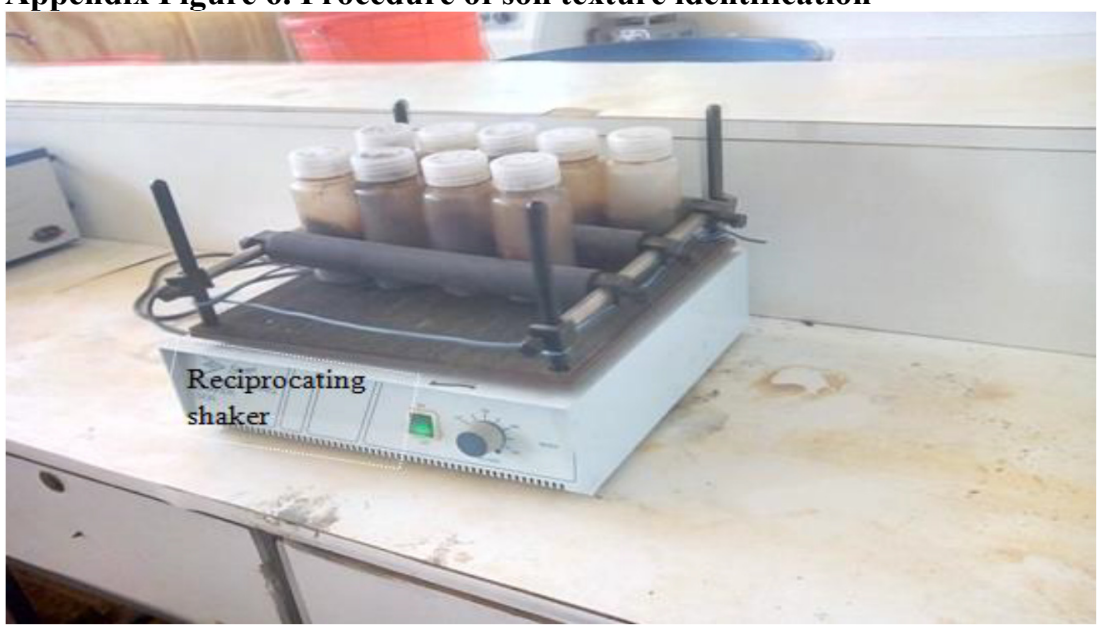

1. Shaker of soil to disperse the particles

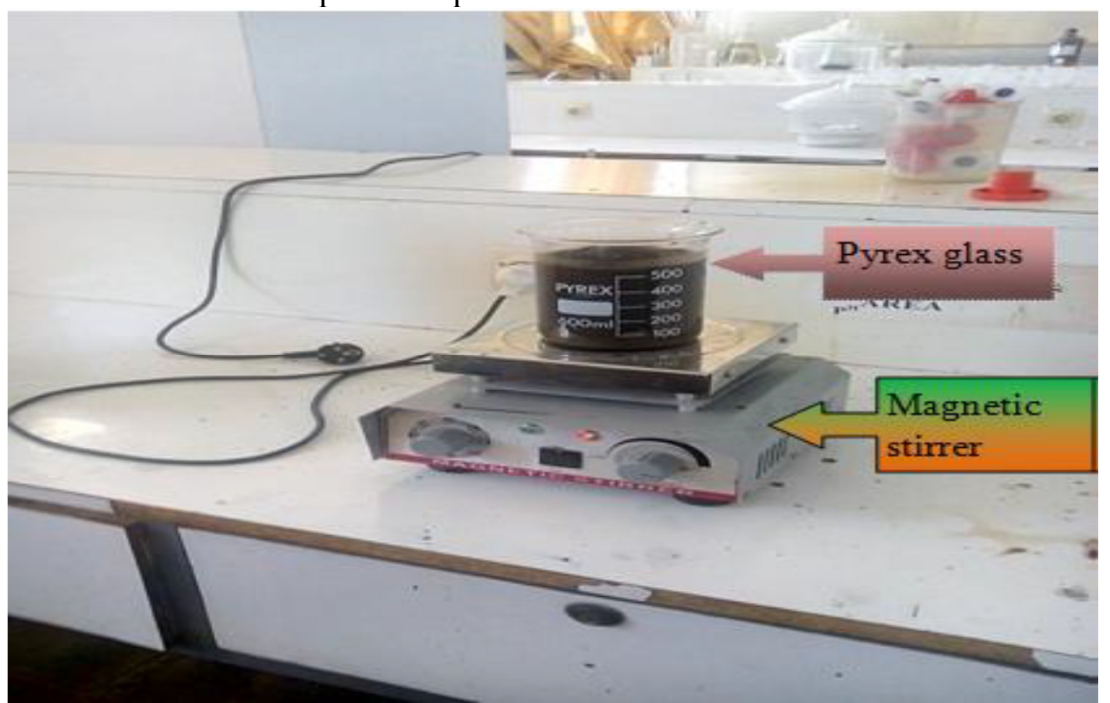

2. Magnetic stirrer to mix shacked soil

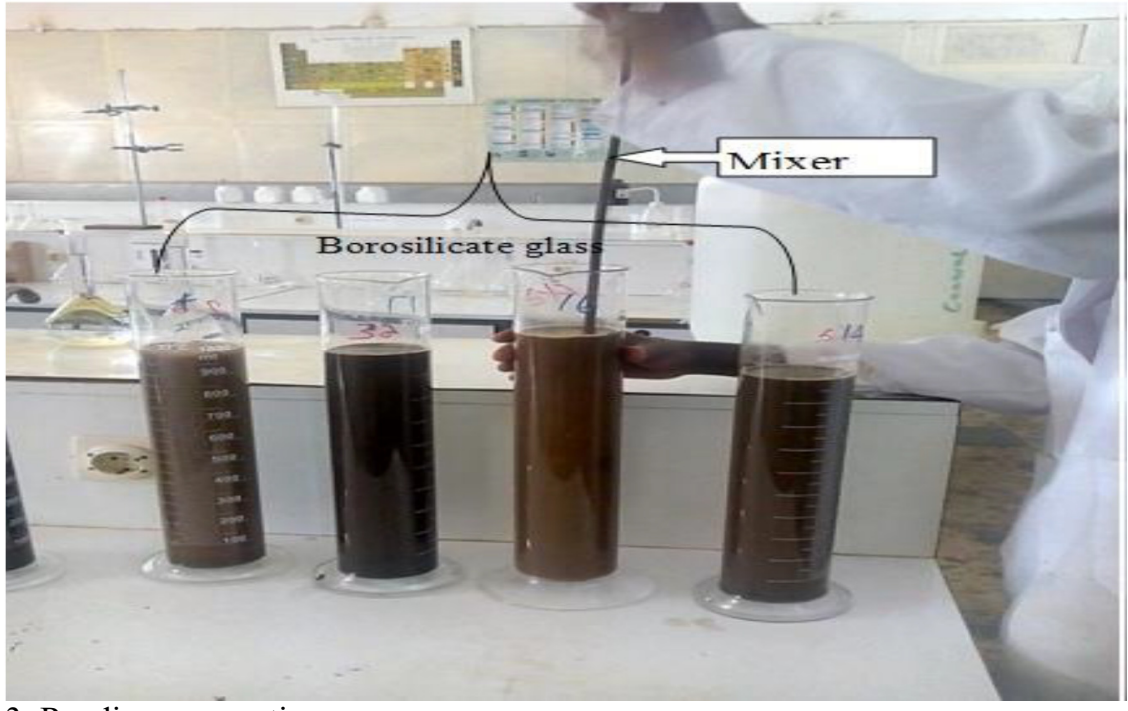

3. Reading preparation 


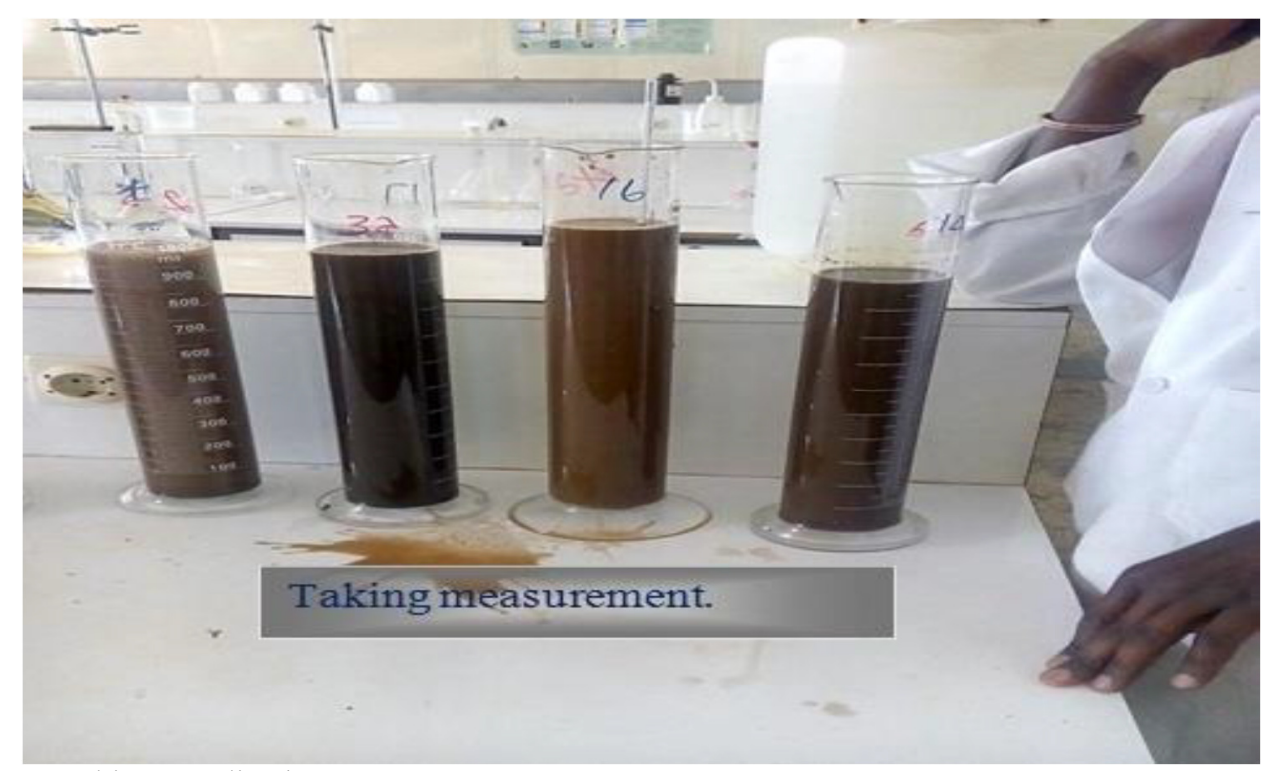

4. Taking Reading/measurements

\subsection{Redesign Procedure of Irrigation Canal}

As the slope of canal bed increased the sediment transportation will be facilitated, so the designing way is to adjust and identify if the bed slope is enough to transport sediment deposited.

\section{Lacey Method}

$$
\mathrm{f}=1.76 \sqrt{\mathrm{dm}}
$$

Where the $\mathrm{dm}$ the average diameter of particle size (coarse sand) deposited in the canal bed which is (2.5) $\mathrm{mm}$.

$$
\begin{aligned}
& \mathbf{f}=1.76 \sqrt{ } 2.5 \\
& \mathbf{f}=\mathbf{2 . 8}
\end{aligned}
$$

Hydraulic Radius $\mathrm{R}=0.473^{3} \sqrt{ } \mathrm{Q} / \mathrm{F}$

Where $\mathrm{Q}$ is the discharge for which the irrigation canal were designed which is $0.02 \mathrm{~m}^{3} / \mathrm{s}$ or $0.71 \mathrm{cfs}$.

$$
\mathrm{R}=0.473 \sqrt{ } 0.71 / 2.8
$$

$$
\mathbf{R}=\mathbf{0 . 3 0} \mathbf{f t}
$$

$$
\begin{array}{ll}
\text { Velocity } & \mathrm{V}=1.17 \sqrt{\mathrm{FR}} \\
\mathrm{V} & =1.17 \sqrt{ } 2.8^{*} 0.30 \\
\mathbf{V} & =\mathbf{1 . 1} \mathrm{fps}
\end{array}
$$

Wetted Perimeter $\mathrm{Wp}=2.67 \sqrt{ } \mathrm{Q}$

$$
\begin{aligned}
& \mathrm{Wp}=2.67 \sqrt{ } 0.71 \\
& \mathbf{W p}=\mathbf{2 . 2 5} \mathrm{ft}
\end{aligned}
$$

Bed Slope $\quad \mathrm{S}=0.000547 \mathrm{~F}^{2 / 3} / \mathrm{Q}^{1 / 6}$

$$
\begin{aligned}
& \mathrm{S}=0.000547 \mathrm{~F}^{2 / 3} / \mathrm{Q}^{1 / 6} \\
& \mathrm{~S}=0.000547^{*} 2.33^{2 / 3} / 0.71^{1 / 6} \\
& \mathrm{~S}=0.000547 * 1.861 \\
& \mathbf{S}=\mathbf{0 . 0 0 1 0 2} \mathbf{f t} / \mathbf{f t}
\end{aligned}
$$

$\mathrm{S}=0.001 \mathrm{ft} / \mathrm{ft}$,

Lacey with Manning General Slope, velocity formula:

$$
\mathbf{V}=1.346 / \mathrm{NaR}^{0.75} \sqrt{\mathrm{s}}
$$

Where $\mathrm{Na}$ is a roughness factor, $\mathrm{n}$ is manning roughness coefficient defined as:

$$
\begin{array}{r}
\mathrm{Na}=0.0225 \mathrm{f}^{0.25}=0.9 \mathrm{nR}^{0.083} \\
=0.0225(2.8) 0.25=0.9 * 0.032 *(0.30)^{0.083} \\
=\mathbf{0 . 0 3}=\mathbf{0 . 0 3}
\end{array}
$$

$=1.346 / 0.03 *(0.30) 0.75 \sqrt{ } 0.001$

$=0.57512$

$=0.6 \mathrm{~m} / \mathrm{s}$ 